\title{
Practical Functioning of a Sustainable Urban Complex with a Park-The Case Study of Stavros Niarchos Foundation Cultural Center in Athens
}

\author{
Beata Makowska (D)
}

Citation: Makowska, B. Practical Functioning of a Sustainable Urban Complex with a Park-The Case Study of Stavros Niarchos Foundation Cultural Center in Athens. Sustainability 2021, 13, 5071. https://doi.org/10.3390/su13095071

Academic Editors: András Reith and Jan K. Kazak

Received: 8 March 2021

Accepted: 27 April 2021

Published: 30 April 2021

Publisher's Note: MDPI stays neutral with regard to jurisdictional claims in published maps and institutional affiliations.

Copyright: (C) 2021 by the author. Licensee MDPI, Basel, Switzerland. This article is an open access article distributed under the terms and conditions of the Creative Commons Attribution (CC BY) license (https:// creativecommons.org/licenses/by/ $4.0 /)$.
Faculty of Architecture, Cracow University of Technology CUT, Warszawska 24, 31-155 Krakow, Poland; bmakowska@pk.edu.pl

\begin{abstract}
Intensive urban development has created a shortage of urban green areas. The need to economically plan and use urban green spaces has fueled the redefinition of public spaces and parks so as to provide the residents with both recreation and relaxation facilities, as well as a forum for contact with culture. This paper discusses the case of the Stavros Niarchos Foundation Cultural Center (SNFCC) in the Kallithea district on the outskirts of Athens, near the Mediterranean Sea. It fills a gap in the research on the aspects of the practical functioning of such facilities. The methodology used in the research included an analysis of the literature, the SNFCC's reports, and an in situ survey. The cultural center hosts a number of events aimed at promoting Greece's natural and cultural heritage. The paper includes a detailed analysis of the events organized by the SNFCC in the period 2017-2020 and their immense impact on residents. The aim of the study is to show that the creation of the SNFCC with the park areas has functioned as a factor contributing to the improvement of the quality of urban space and the quality of life of the city's inhabitants. The paper's conclusions indicate that the sustainable SNFCC project, which fulfils the urban ecology criteria, has been very well received by the visitors-citizens and tourists alike. A program-centered innovation introduced by the SN Park has added great value to their lives. The project contributes to economic and cultural growth, as well as the protection and promotion of heritage.
\end{abstract}

Keywords: urban park; sustainable cultural complex; cultural heritage

\section{Introduction}

Rapid urbanization is one of the main drivers of environmental change. Therefore, flexible and sustainable development of contemporary cities is a key element, which can provide a better place for living and recreation [1]. As the space for green areas becomes ever scarcer in the cities, it has become necessary to introduce an innovative approach to the design of parks [2,3], whose impact on the improvement on the living conditions of residents has now been scientifically recognized [4]. Parks ensure a more balanced relationship to the natural environment in the urban context and improve both the quality of life of the city's residents and the quality of urban space $[5,6]$. Their aesthetic values boost the attractiveness of the working spaces, residential areas, and recreation sites. Parks may also encourage a variety of social activities-neighborhood meetings, direct interpersonal contacts, or the promotion of active and healthy lifestyles. Some recent implementations have shown that parks may attract tourists thanks to their avantgarde solutions and become major components affecting the image of cities, ensuring their profitability $[7,8]$. Moreover, they may also facilitate the integration of urban spaces, improving their quality and contributing to the activization of their surroundings $[9,10]$. The 21st century necessitates, once again, the unification of physical urban structuresbuildings, spaces, streets, and green areas-with the cultural, social, and economic aspects of city life [11]. The new projects introducing greenery to crowded cities create spaces that are friendly, safe, and open to all residents. Architectural forms and parks linked to 
the cultural heritage of a specific region [12,13], as well as to its topography and natural elements, are extremely important for sustainable development and have an immense influence on the residents [14].

One excellent example of such a case is the Stavros Niarchos Foundation Cultural Center (SNFCC) project analyzed in this paper. The project allowed for the reclamation of a degraded area. It also merged adjacent spaces in Athens into a coherent urban structure, preventing their fragmentation. The new buildings and the park have blended well into the urban landscape which may be admired by visitors thanks to the observation decks and sightseeing platforms. The links created with the existing vegetation and culture promote the socialization of residents and strengthen their sense of belonging to the place. This innovative approach to the creation of recreational and educational space may be referred to as 'urban fabric remodellation'. One of the main goals of the SNFCC's interdisciplinary project was to reconnect the residential area with the sea, separated by the highway, and create a new type of open public area within the park. The site has functional linkages with sport facilities in the neighborhood (the Kallithea Municipal Swimming Pool, among others) and compositional reference to the Acropolis, which emphasizes the north-south axis towards the sea.

The initial idea of SNFCC project (proj. Renzo Piano Building Workshop, 2012-2016) was the creation of a hill and buildings as a-topos-(in Greek: tópos koinós), a significant place which 'cannot be created, but rather becomes' [15]. For this purpose, Renzo Piano designed a park stretching over the rooftops of the associated cultural facilities, thus creating a special place that establishes a spatial dialogue with the Acropolis hill. The complex consists of the National Library of Greece (NLG) and the Greek National Opera (GNO), the Agora between them, and the Park. Renzo Piano has created an urban square surrounded by the most important buildings for culture - the library and the opera housethe 'two pillars of civilization' [15]. The buildings are translucent; thus, their function is visible from the outside. Their facades emphasize the ecological building performance. Characteristic for their structures is the lightness of the spaces and their transparency. The books at the National Library of Greece, the performances at the Greek National Opera, the cultural events, and the exhibitions taking place at the SNFCC all provide an insight into the Greek culture. It is a 'microcosm of the country' [15]. The interdependence of culture and nature within this interdisciplinary project has contributed to the popularizing of local heritage. The square (Agora) between the buildings with the canal open to the city creates an interesting multi-functional space for the organization of events (Figure 1). The agora has always had an important place in Greek culture.

The SNFCC in Athens was chosen as a case study as one of the best examples of a sustainable approach to design and management which enhances Greece's image internationally. The relevance of the SNFCC project has been confirmed by the award of the Platinum LEED certification - the highest rating possible in terms of green design and construction standards. This is the only public building complex in a park of this size and complexity in Europe [15]. It has exceptional environmental standards and has become a landmark of this Kallithea area [16].

The SNFCC and the other buildings of major cultural institutions with the LEED Platinum have radically changed our perception of the public space and the park, e.g., Vestas Technology and Development Center in Århus, Denmark; Water and Life Museums in Hemet, USA; Park Ventures in Bangkok, Thailand. Those projects help cities to improve their international competitiveness and attract foreign visitors.

The SNFCC structures and their resistant materials are environmentally sustainable and enable the minimal waste of water and energy resources. The designers used, for instance, trees formerly growing in this area, local materials, and those which came from the demolition of old buildings. Many local workers worked there, which was important in the context of the financial crisis related to Greece's debt. One great advantage of this project was also the flexibility in the designers' approach. They made many adjustments during the construction period in order to improve the quality of the complex. One example 
was the reduction in the canopy size and its construction costs (the total cost of the SNFCC reached EUR 630 million).

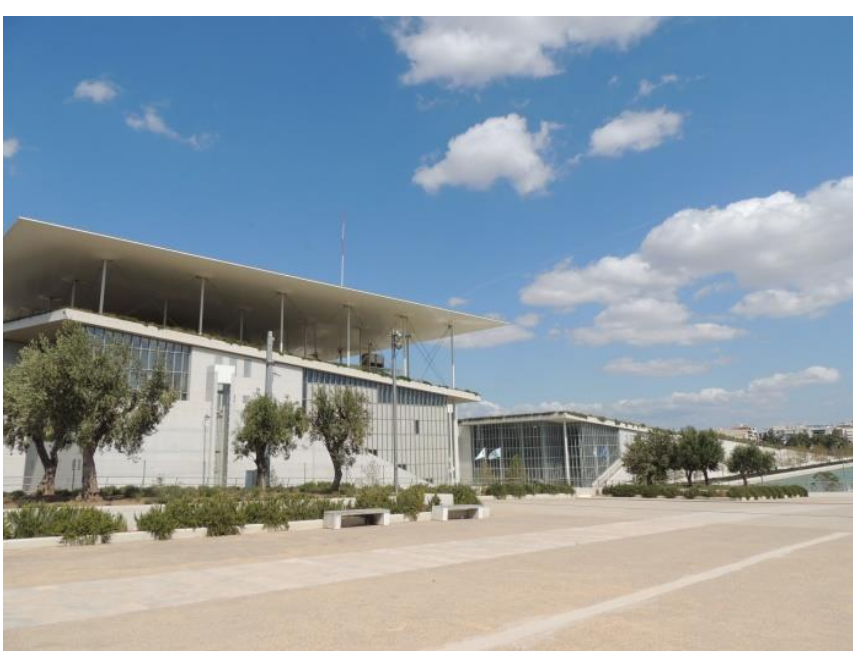

(a)

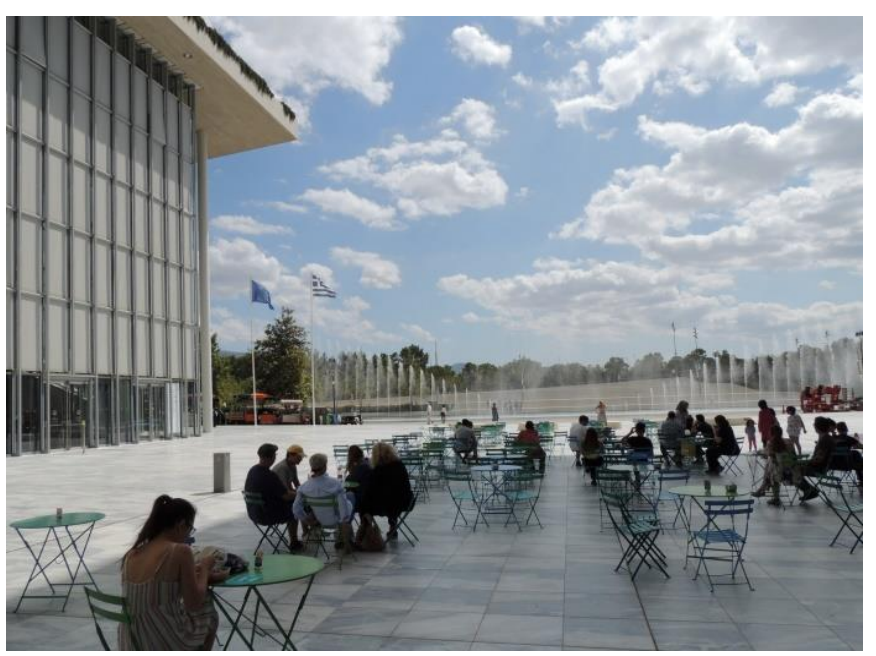

(b)

Figure 1. The SNFCC: (a) the Greek National Opera (GNO) and the National Library of Greece (NLG); (b) the Agora, photos by B. Makowska, 2019.

This paper fills a gap in the research on the details of some aspects of the practical functioning of the SNFCC. The study aims at filling some of the gaps in the existing research concerning the project and its relevance to the actual functioning of sustainable development in practice. It covers the issues related to the building structure (including a comparison of the canopy panels' efficiency against the mean temperatures, the number of daylight hours and sunshine periods in Athens) as well as the urban ecology and education programs carried out at the site. The study comprises a detailed analysis of the number and category of events organized by the SNFCC in the period 2017-2020. Based on the data available, the numbers of participants were identified, including those who took part in the events remotely in 2020, as a result of the difficult circumstances caused by the COVID-19 pandemic. The obtained results emphasize the importance of the project, its relevance to the residents of Athens and the immense impact scale. They may also popularize an excellent model of sustainable management, which can inspire other cultural and educational complexes.

\section{Materials and Methods}

The methodology used in the study included an analysis of the printed literature and online sources. It relied on the latest scientific publications concerning the SNFCC project and an analysis of the practical implementation of sustainability in urban design. The analyzed sources included, among others, the SNFCC's Reports [17], the Impact Detailed Report prepared by The Boston Consulting Group [18], and the SNFCC's monthly Booklets [19]. Additionally, a variety of reports concerning Athens were studied: the city population censuses, the climate, the greenery [20], and other documents which were associated with the protection of cultural and natural heritage of the city.

One important publication concerning the SNFCC is the book written by Victoria Newhouse in 2017 entitled 'Chaos and Culture: Renzo Piano Building Workshop and the Stavros Niarchos Foundation Cultural Center in Athens'. The basic information is also available at the SNFCC's official Internet pages [. This study contains an analysis of publicly available reports published on that website. Many scientific papers raise the problem of the project's adaptation to sustainable design [21] and the use of innovations [22], the protection against flooding and earthquake resistance, including special columns in a base-isolation system as an element of seismic protection. Scientists have also undertaken research on the potential 
introduction of tickets to the Park based on the surveys among residents [23]. Other interesting studies concerned the improvement of the complex's accessibility by public transport from the city center and connecting the sites by building bikeways and pedestrian paths [24] — unfortunately, problems with soil erosion did not allow for the construction of an underground line which would connect the SNFCC with the center of Athens.

This paper is also based on in situ survey carried out in 2019. On that occasion, photographic documentation of the park and the architectural structures-including their interiors-was prepared during an excellent guided tour.

Thanks to the accessibility of data, this paper includes a chart illustrating the efficiency of the canopy panels in the period 2017-2019 as compared to the mean temperature throughout the year, the number of daylight hours, and sun exposure in Athens. Furthermore, an analysis of the changing number of events organized at the SNFCC and the visitors in the period 2017-2020 has been included. For this purpose, official reports were used, supported by a detailed analysis of the programming booklets prepared for every month. The results concerning the proportions between the specific groups of events organized at the SNFCC have been presented in tables and in charts. The charts have been contrasted against the programming assumptions of the SNF foundation regarding the financing of specific fields. The aim was to emphasize the transparency of the foundation's objectives and the practical implementation of its declared goals. The charts representing the proportions between all the events organized at the site allow us to draw conclusions regarding those that are in highest demand and most popular among residents.

\section{The Studied Area of the Stavros Niarchos Park and the District of Kallithea}

\subsection{The Stavros Niarchos Park}

The Stavros Niarchos Park (SN Park) is an integral part of the SNFCC which covers $85 \%$ of site. It was designed by Deborah Nevins \& Associates according to Renzo Piano's scheme which emphasizes the movement toward the sea. It combines Italian, French, and English forms [25]. The park located on the building's roofs and the surrounding area offers spectacular panoramic views of Athens (Figure 2) - the sea and Faliro Bay, the mountains, Acropolis, and the city. According to Nevins, the park is a repository of the botanical culture of the region-in the same way as the library is 'a repository of Greek and Mediterranean culture' [15]. The project emphasizes the urgency of preserving indigenous endangered species. It also broadens knowledge about them and popularizes them in future public park design. Little-known Greek species were introduced there and used in a public park for the first time. The plants were adopted in order to cool down the paved area for public activities.

In this project, the key challenge involved the climatic extremes-especially between June and September-high temperatures with little rain on the one hand, and floods caused by downpours on the other. Such conditions created a hostile environment for plants. Another problem at the Park was the absence of a steady and reliable source of water and the inability to use the city sewage system, which was already operating at full capacity. That is why Nevins chose drought-resistant plants which were irrigated by roots. The second source of irrigation water is a canal filled with seawater, which is desalinated before use. The canal also serves as runoff in case of flood. Implemented at the SN Park, water management has significant impact on the ecology, e.g., use of rainwater, use of plants with lower irrigation requirements, replacement of surface irrigation with dripping irrigation, and the reuse of wastewater.

The Stavros Niarchos Foundation's aim was to create a flexible and freely accessible place, which would be open for easy programmatic use. Nevins designed a park which was inspired by the Greek landscape and reflected the soul of Greece-with characteristic olive trees, pines, native herbs, water, and stone. All the plants are low maintenance because they are drought-tolerant and wind-resistant (there are about 1400 trees and 310,000 shrubs and perennials). The weight was also an important factor in selecting plants located on buildings' roofs. Characteristic for Greek landscapes is the prevalence of iconic olive trees. 
Nevins used them as focal points in the garden. One of the disadvantages of introducing olive trees in the Park is their slow growth - they may never grow tall enough to provide protection from the sun. It was also difficult to import and transport mature trees from abroad [25]. Nevins also had a problem with the soil, which needed careful preparation for successful planting, because the park is located on a hill.

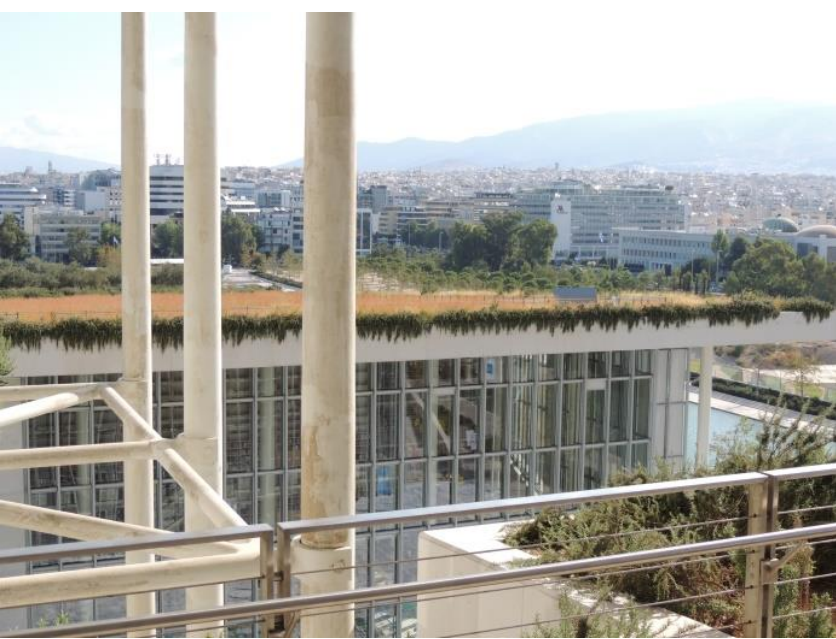

(a)

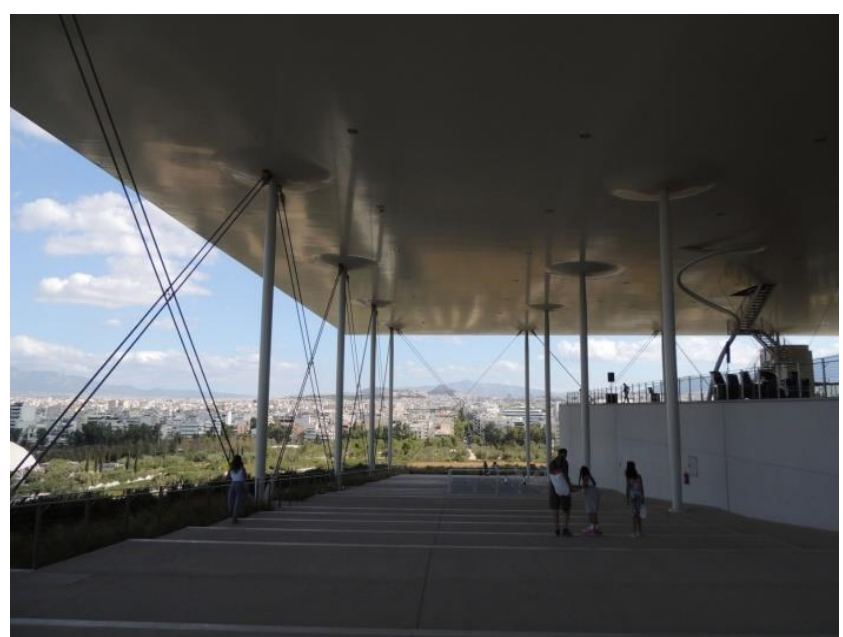

(b)

Figure 2. Views from the terraces of the SNFCC's buildings: (a) view towards the north-east; (b) view towards the north; photos by B. Makowska, 2019.

The Great Lawn in the Park is a central place for recreation, concerts, festivals, films, and sport events. In the park, there is also a splash pool, labyrinth ('a meditation tool'), several children's playgrounds, and a green area arranged geometrically, mainly using endemic plants (Figure 3).

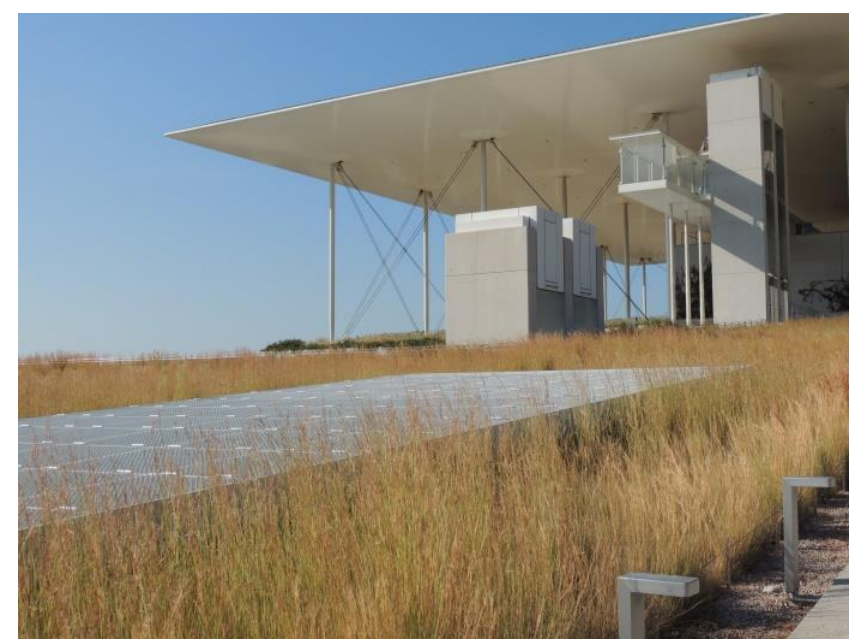

(a)

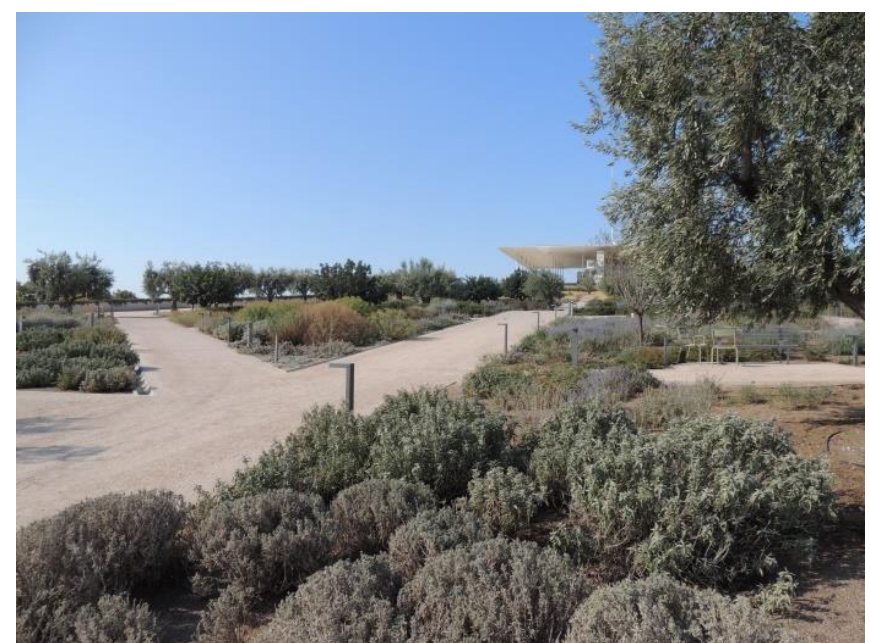

(b)

Figure 3. The Stavros Niarchos Park in Athens: (a) endemic plants; (b) shrubs and trees; photos by B. Makowska, 2019.

Nevins cited local agricultural forms (hedgerows and groves) with an ordered grid of orchards_-arranged in straight and parallel rows (Figure 4). 


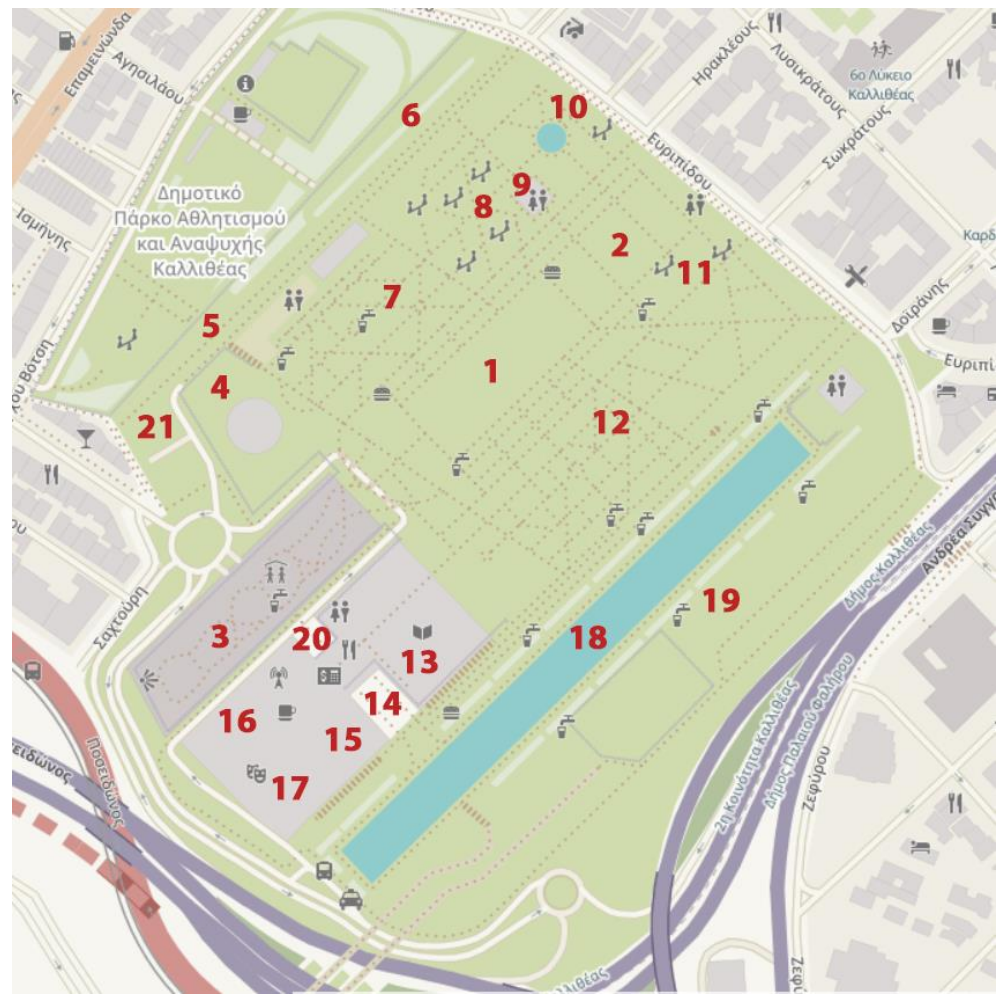

1 Great Lawn

2 Pine Grove

3 Southern Walks (on the roof)

4 Labyrinth

5 Outdoor Gym

6 Running Track

7 Western Walks

8 Playground

9 Café

10 Splash Pool

11 Sound Garden

12 Mediterranean Garden

13 National Library of Greece

14 Agora

15 Greek National Opera

16 Lighthouse

17 Panoramic Steps

18 Canal

19 Esplanade

20 Small Agora

21 Outdoor Parking Lot

Figure 4. The map of the SNFCC (the green color marks the area of the SN Park and sport facilities on the north-west side, i.a., the Kallithea Municipal Swimming Pool)_based on: OpenStreetMap.

\subsection{The Stavros Niarchos Park Versus Greenery in Athens}

In 2016, there were only 9059 ha of green areas in Athens, which accounted for as little as $13.8 \%$ of the total area of the city (only green areas with a surface area in excess of 0.25 ha were taken into account) [20]. The estimated surface area of the city is 65,594 ha. The southern and south-western parts of the city have particularly little green areas, which is why the creation of the Stavros Niarchos Park is so important for the Kallithea residents (Figure 5).

It has a surface area of about $210,000 \mathrm{~m}^{2}$. Even though in the context of the entire city it accounts for a small percentage of green areas $(2.3 \%)$, the role of the park with its innovative and diverse educational, cultural, and recreational benefits cannot be underestimated. A highly flexible approach to adjusting the programming to the current issues is a major advantage of the institution. In 2018, it was estimated that there were $3.99 \mathrm{~m}^{2}$ of park areas, $1.64 \mathrm{~m}^{2}$ of forest and woodland, and $0.14 \mathrm{~m}^{2}$ of maintained grass per capita. In total, this adds up to $5.77 \mathrm{~m}^{2}$ per inhabitant [26]. Compared to other cities, this value is, unfortunately, quite low. Although there are differences in the total amount of urban green spaces in the cities in different datasets [27], Athens fares badly in many of them. According to the research carried out in 2017 in 43 European capitals, Athens ranks last from the perspective of urban green areas [28]. By contrast, in London, urban greenery is distributed more evenly throughout the city and is much more abundant (Figure 6) - it takes up ca. 40\% of the urban area [29], which is triple the percentage recorded in Athens. In 2015, green urban spaces in larger cities in Poland (the total share of forests and woodlands, parks, green enclaves and urban greenery in residential areas) corresponded to $46 \%$ of the city area in the case of Katowice, 19\% in the case of Warsaw, 18.5\% in Poznan, 12\% in Wrocław, with Krakow tailing with only $9 \%$ [30]. 


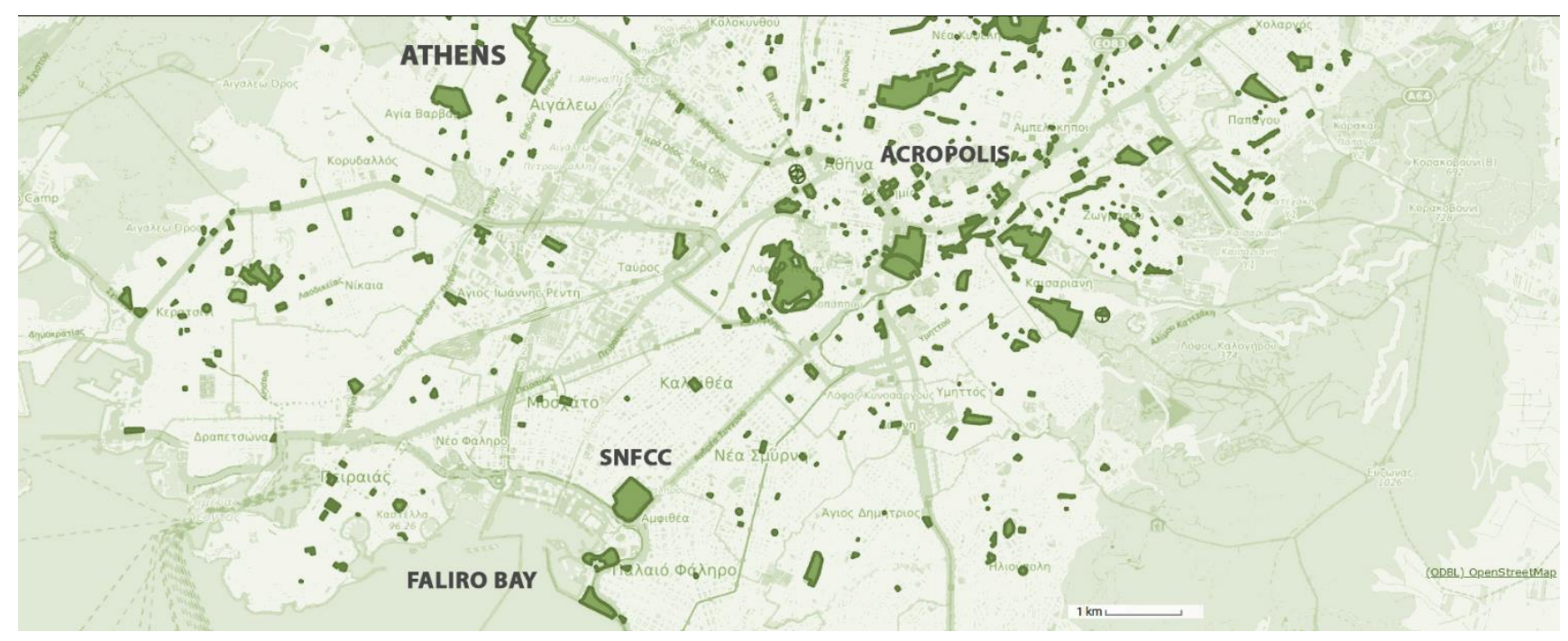

Figure 5. Greenery in Athens-based on: OpenStreetMap https:/ / query2map.toolforge.org/ queryinmap.php?name=*\& key $=$ leisure $\&$ value=park\&types $=$ points-areas\&BBOX $=23.5387,37.8909,23.9387,38.0909$ (accessed on 2 September 2020).

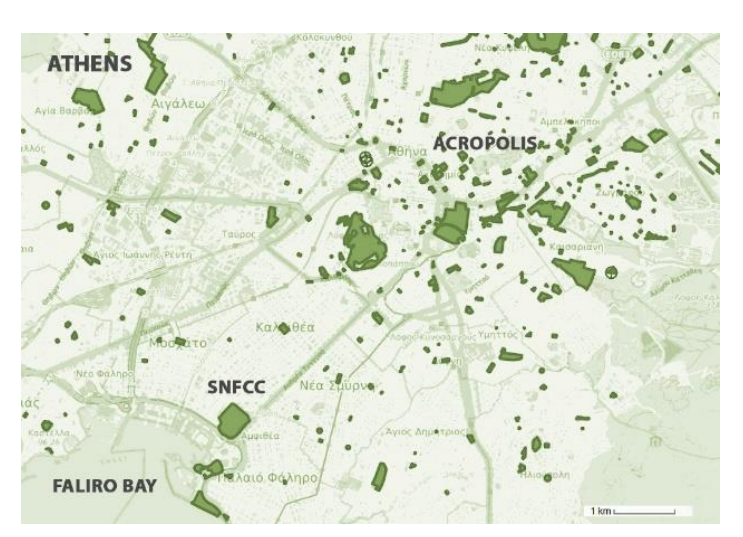

(a)

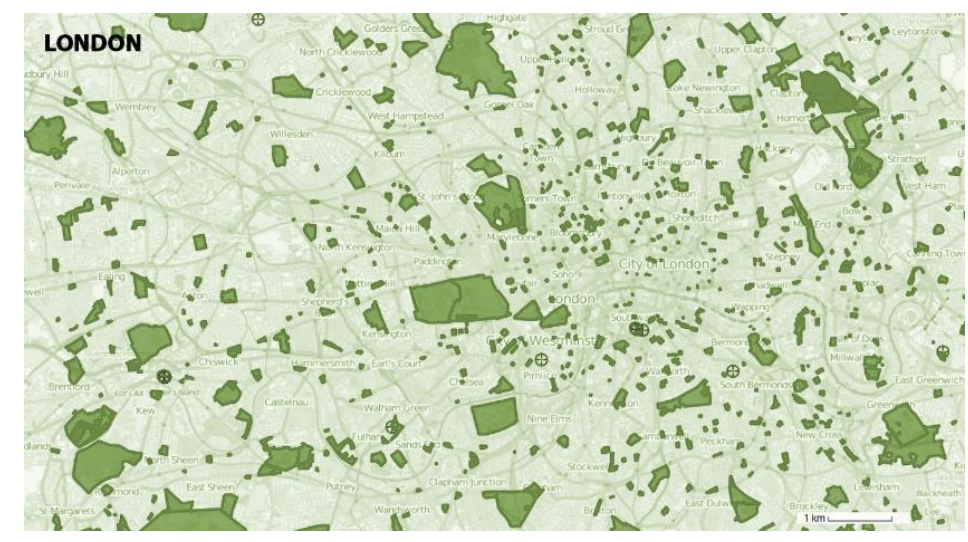

(b)

Figure 6. A comparison of green spaces: (a) in Athens; (b) in London-based on: OpenStreetMap https: / / query2map.toolforge.org / queryinmap.php?name=*\&key=leisure\&value=park\&types=points-areas\&BBOX=-0.3 2766,51.40732,0.07234,51.60732 (accessed on 2 September 2020).

According to the Impact Detailed Report FROM the Boston Consulting Group, the SN Park has 'doubled the green surface per capita in the area (including Kallithea, Moshato, Paleo Faliro and Nea Smirni, excluding cemeteries, football stadiums), bringing with it distinct health benefits (exercise and clean air)' [18]. It has already enhanced the local ecosystem and biodiversity. The SN Park supports biodiversity by plant selection, which creates a sustainable ecosystem, implementing green roofs which integrate the buildings with the Park (thermal and noise insulation of the opera and the library, rainwater collecting), using natural and recycled materials in pathways, playgrounds, etc. The benefits are already there: birds and bees have come back to the Kallithea area. The SN Park's vegetation has a positive impact on the micro-climate and decreases the temperature in the neighboring areas.

\subsection{The District of Kallithea-Population and History}

The district Kallithea is situated near the Faliro Bay, and its name means a 'beautiful view' (in Greek: $K \alpha \lambda \lambda_{\imath} \theta \dot{\varepsilon} \alpha$ ). It is located in the south-western part of Athens (Figure 7). 


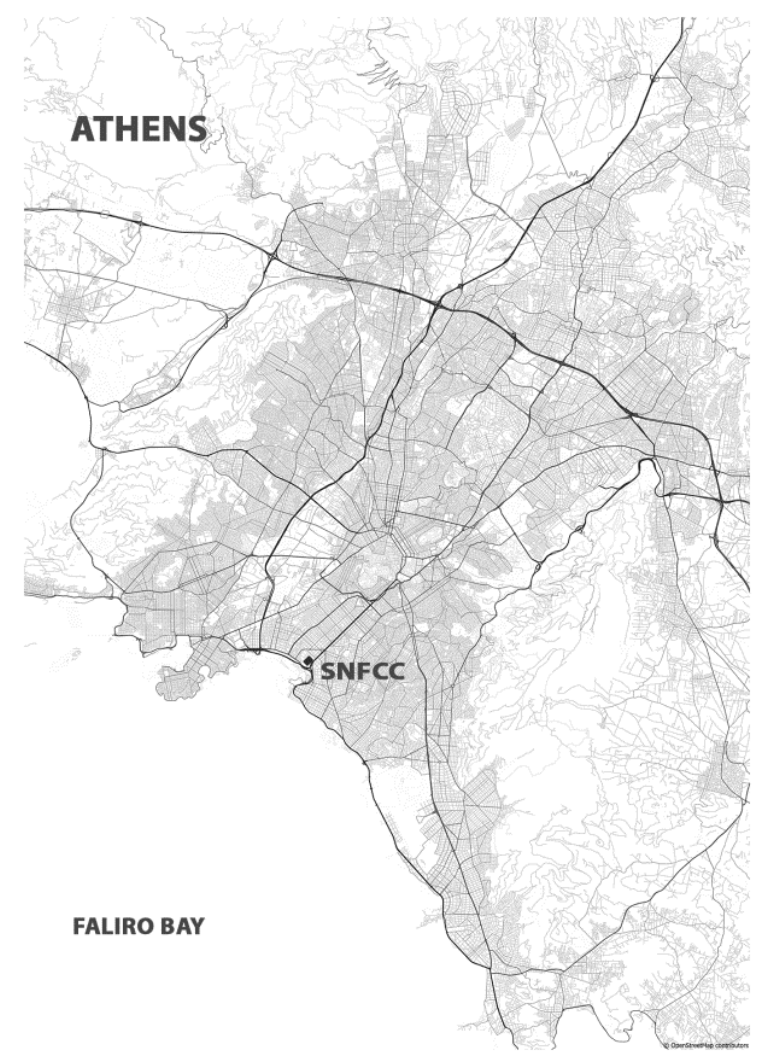

(a)

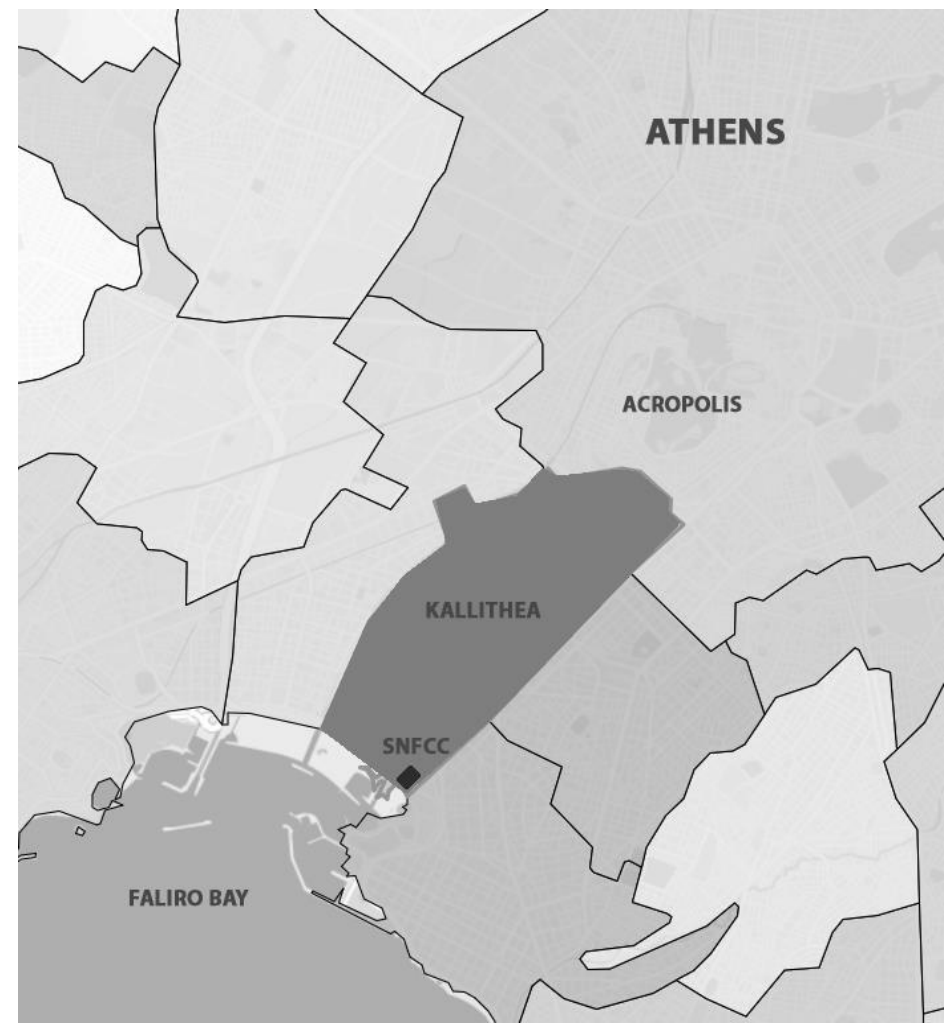

(b)

Figure 7. The location of the SNFCC: (a) on the map of Athens-based on: OpenStreetMap https://wiki.openstreetmap. $\mathrm{org} / \mathrm{w} / \mathrm{images} / \mathrm{a} / \mathrm{ad} /$ Athens.pdf (accessed on 2 September 2020); (b) in the Kallithea district in Athens.

Before the SNFCC was created in the Kallithea district, there were no open green spaces there, except the Park near the Church of Metamorphosis Sotiros (Ieros Naos Metamorfosis Sotiros), the small green area near the corner of Praxiitelous and Agisilaos streets, and the

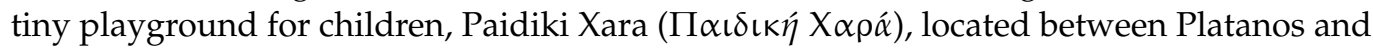
Achilleos streets. Nowadays, SN Park is the key and most important green area of the district. In order to present the researched issues in a broader context, an analysis of the fluctuations in the number of residents and the population density in the Kallithea district where the SNFCC is located was carried out for the period 1981-2020. For this purpose, the data available from the General Secretariat of National Statistical Service of Greece, i.e., population censuses, were used [31]. Kallithea, with an area of $4.75 \mathrm{~km}^{2}$, is now among the most densely populated districts in Athens [32]. In the years 1928-1940, the density in this district was estimated at 5-10 inhabitants $/ \mathrm{km}^{2}$; in the years 1951-1961, between 10 and 15 inhabitants $/ \mathrm{km}^{2}$; in the year 1971, at over 20 inhabitants $/ \mathrm{km}^{2}$; and in the period 1981-2001, the density ratio reached almost 25 inhabitants $/ \mathrm{km}^{2}$ [33]. The density slightly decreased in the year 2011, it reached 21.188 inhabitants $/ \mathrm{km}^{2}$ (Table 1). 
Table 1. Population and density of the Kallithea district ${ }^{1}$.

\begin{tabular}{ccc}
\hline Year & Population of the Kallithea District & Density (Habitants $/ \mathbf{k m}^{\mathbf{2}}$ ) \\
\hline 1981 & 117,319 & 24,699 \\
$1991^{2}$ & 116,731 & 24,575 \\
$2001^{3}$ & 115,150 & 24,242 \\
$2011^{4}$ & 100,641 & 21,188 \\
$2020^{5}$ & 100,641 & 21,188 \\
\hline
\end{tabular}

${ }^{1}$ Source: ELSTAT, Population censuses, https:/ / panorama.statistics.gr/ (accessed on 2 September 2020); ${ }^{2}$ Ac cording to the population census from 17 March 1991; ${ }^{3}$ According to the population census from 18 March $2001 ;{ }^{4}$ According to the population census from 16 March 2011; ${ }^{5}$ Source: https:/ / worldpopulationreview.com/ countries / cities / Greece (accessed on 2 September 2020).

It is estimated that more than 250,000 people live in Kallithea or are passing by (among them the SNFCC visitors) or working there on a daily basis. The fluctuating population density of the Kallithea district is related to its history. This district was established by the Euthymios Kehagias' Building Company in 1884 [34]. At that time, many houses there were designed by the German architect Ernst Ziller (1837-1923). At the turn of the 19th and 20th centuries, the areas at the Faliro Bay were a popular recreation site among residents of the capital (Figure 8). Water (the Faliro Bay) and greenery (the SN Park) are key elements of creating a good quality housing environment in the nearby Kallithea (Figure 8).

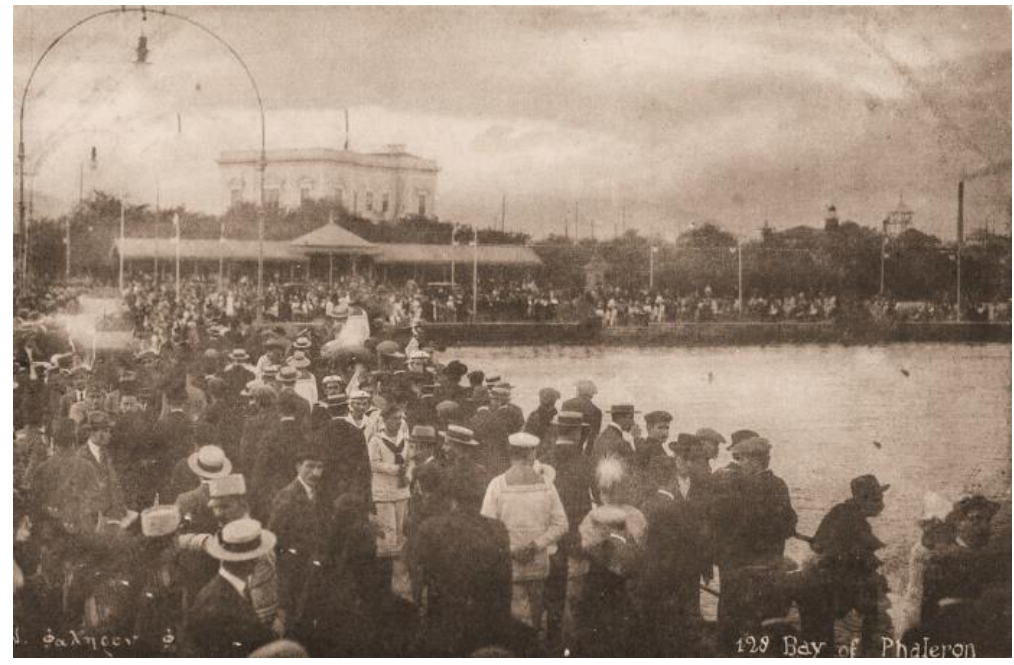

(a)

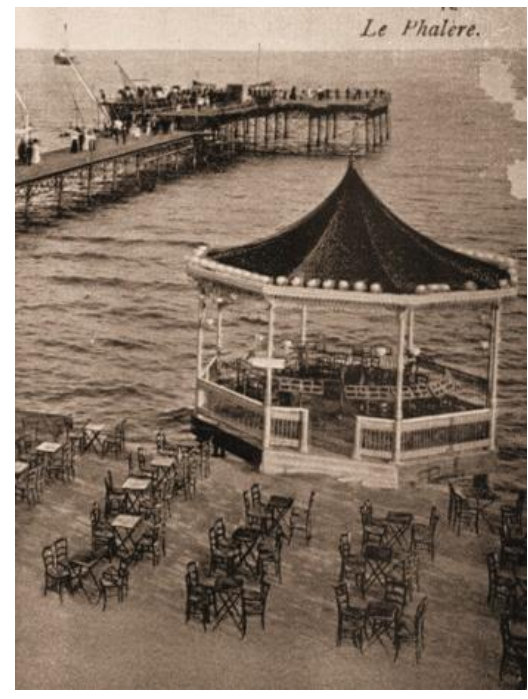

(b)

Figure 8. Faliro Bay in Athens: (a) a postcard from July 1901, source: https:/ /twitter.com/CCavafy/status/10207027852628 17280/photo/1 (accessed on 2 September 2020); (b) a postcard from about 1900, source: https://www.pinterest.it/pin/3464 95765057211224 / (accessed on 2 September 2020).

In that period, the number of residents of the district gradually increased. This process was fueled, among other things, by the construction of sports facilities and the organization of the Olympic games-the Summer Olympics took place at the Kallithea Skopefterion in 1896 [35]. Unfortunately, later, the construction of a motorway cut this part of the shore off from the city, decreasing the district's attractiveness. The SNFCC project restores the link between the residential areas and the sea, making it a popular recreation site, just like at the turn of the 19th and 20th centuries.

The Kallithea district has also attracted numerous immigrant residents-'Kallithea has a variety of population groups that settled here from the early 19th century up to nowadays. Most of them are expatriate-refugees who return to Greece from Asia Minor and the coastal areas of the Black Sea as well as expatriate and immigrants from Russia, Czech Republic and other eastern European countries. All these groups have a quite diverse 
cultural background that gives Kallithea a quite multicultural life' [36]. In the 20th century, Kallithea became a major center of artistic and intellectual activity. Many renowned writers, poets, painters, and sculptors have lived there.

\section{4. 'Sustainability' of the SNFCC's Structure-The Efficiency of the Canopy Panels}

The sustainable approach to design can be observed in the structure of the GNO and NLG buildings, as well as in introducing Ecosystem Services which moderate natural phenomena, i.a., flood control, water purification and climate regulation. All systems at the SNFCC have been designed to save energy, such as heating, air conditioning, or lighting. One of them is the innovative ferro-cement construction which was used to create the canopy above the Opera building. It supports technologically advanced solar panels. The canopy panels with 87,000 square feet of photovoltaic cells are expected to meet $15 \%$ of the facility's demand for electricity [15]. According to information from the SNFCC's official page, the canopy can cover $100 \%$ of energy needs-although only at certain times (e.g., depending on the number of visitors) [19]. The technologies applied allowed for the integration of the form and materials. The handmade methods of construction required sophisticated analysis within a millimeter of tolerance.

To better illustrate the functioning of the sustainable project in practice, this paper includes a comparison of the canopy panels' effectiveness in particular months. Based on the data available on the SNFCC website, a comparative analysis of the panels' efficiency in the period 2017-2019 was carried out (Figure 9). The paper compares the range of efficiency of the panels against the mean temperatures in Athens [37] during the year (Figure 10). A clear dependence between these factors is observable in the similarities of the charts onto which the data have been plotted.

\section{Energy (kWh)}

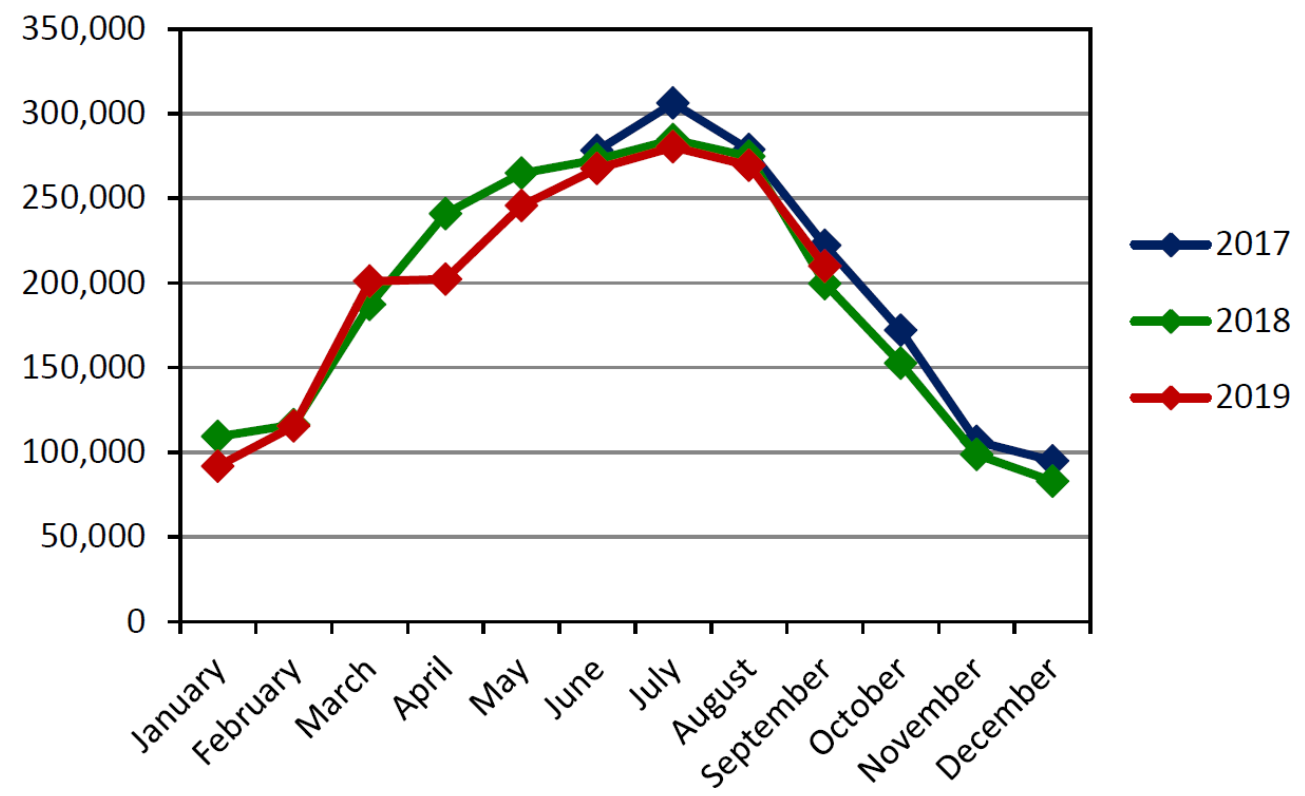

Figure 9. Energy $(\mathrm{kWh})$ from the canopy panels during each month in the years 2017-2019-based on: https:/ / www.snfcc.org/en/sustainability-hub (accessed on 2 September 2020). 


\section{Average temperature $\left({ }^{\circ} \mathrm{C}\right)$}

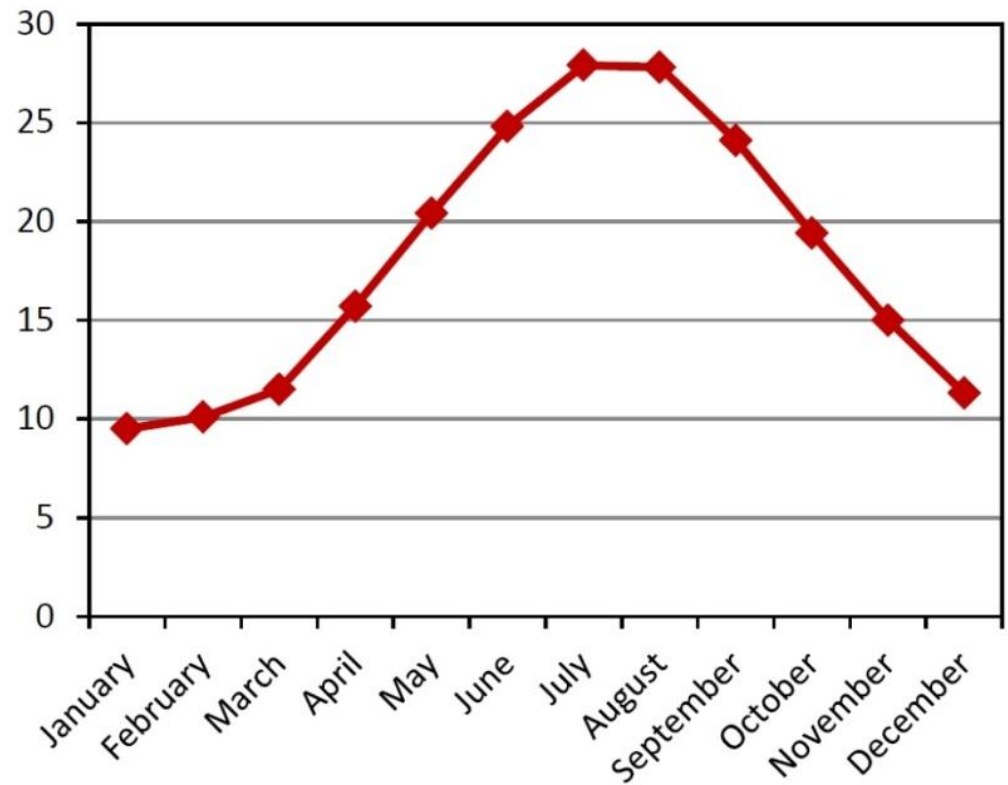

Figure 10. Average temperature in Athens during each month-based on: https:/ /en.climate-data. org/europe/greece/athens/athens-7/ (accessed on 2 September 2020) [37].

Likewise, the chart illustrating the changes to the length of the daylight hours and sunshine hours throughout the year (Figure 11) shows similarity to the chart presenting the efficiency of solar panels, which is closely related to sunshine hours [38]. In Athens, June is the month with the longest days (with average daylight of $14.8 \mathrm{~h}$ ), and December is the month with the shortest days (with average daylight of $9.6 \mathrm{~h}$ ). July and August are the months with the most sunshine (with average sunshine time of $12 \mathrm{~h}$ ), and January is the month with the least sunshine (with an average of $5.6 \mathrm{~h}$ ).

(h)

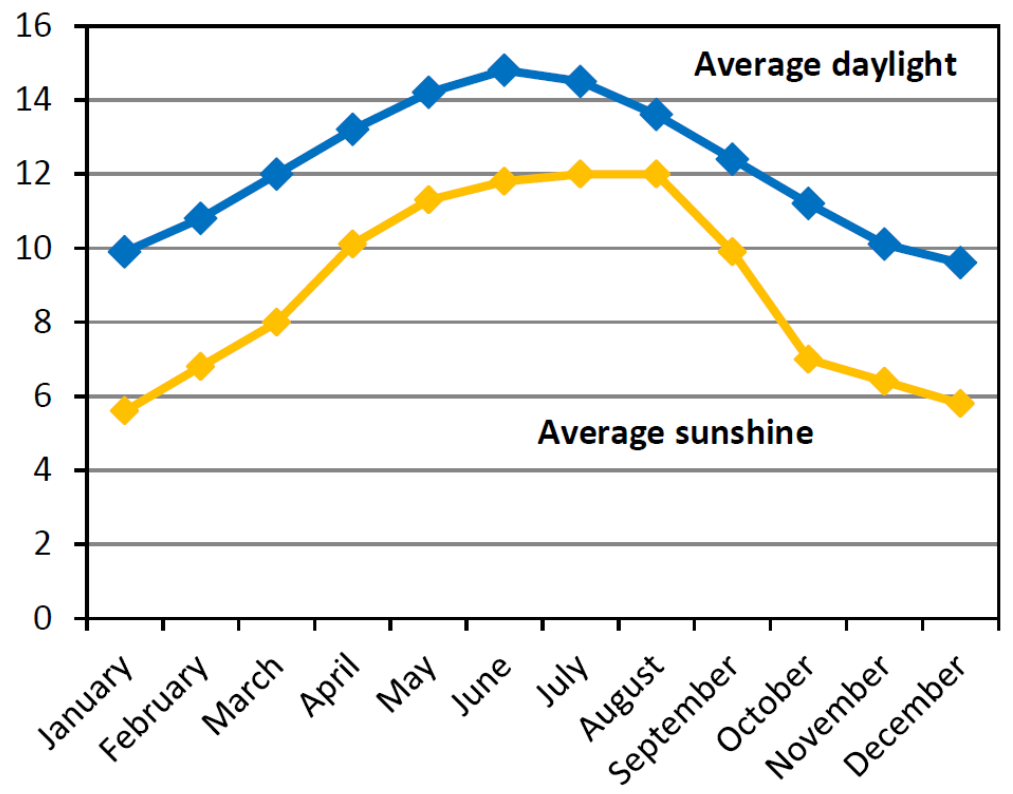

Figure 11. Average daylight hours and sunshine hours in Athens-based on: https:/ /www.weatheratlas.com/en/greece/athens-climate\#daylight_sunshine (accessed on 2 September 2020). 
The foregoing charts show a clear relationship between the efficiency of the canopy panels and the mean temperature and the length of the sunshine hours throughout the year. Given the global trend of raising temperatures, one should expect that the efficiency of the panels will proportionally increase over the coming years. The increase in temperatures is particularly noticeable in Europe. According to the Copernicus Climate Change Service, December 2019 in Europe was more than $3.2^{\circ} \mathrm{C}$ warmer than the December average for 1981-2010 (globally, the temperature was $0.7^{\circ} \mathrm{C}$ higher) [39].

The SNFCC is characterized by transparency in terms of analyzing and presenting the data on sustainable design and approach. Its official website in 2017 disclosed the following data:

- The photovoltaic panels on the Energy Canopy were activated in May, meeting 27.98\% of the SNFCC energy consumption needs from June to December 2017 [40];

- 'The operation of critical systems, such as air conditioning, were optimized to minimize power consumption. Natural gas consumption was reduced by $21 \%$ (comparison periods: May to December 2016 and 2017)' [17];

- 'Thanks to proper planning and streamlining, a 23\% reduction in irrigation consumption was achieved' [19] (comparison periods: April to September 2016 and 2017).

- 'SNFCC's energy efficiency initiatives result in a $40 \%$ energy reduction compared to what a similar building complex would consume without their implementation' [40];

- 'Energy efficiency initiatives contribute to annual energy savings of 7.4 GWh, equivalent to 2750 tons of $\mathrm{CO}_{2}$ and $\sim$ EUR 0.6 million saved annually' [41].

\section{Results}

\subsection{The Number of SNFCC's Visitors}

This paper contains an analysis of the changing number of visitors to the SNFCC in the period 2017-2020. The data on the number of visitors presented in the table (Table 2) come from the official SNFCC website [42] and have been supplemented with the mean values calculated for the three years and the mean number of visitors per day. The estimated mean number of SNFCC visitors in the period 2017-2019 was more than 13,000 per day. The number of the SNFCC visitors is variable and depends on the season of the year, the day, and the events being organized. The site attracted the largest crowds during weekends (especially Saturdays and Sundays at ca. 18:00-19:00; the place was also slightly busier at lunchtime, ca. 13:00) as well as during the summer months and on the days of major events. The SNFCC provides real-time information on the visitor concentration levels every day. This allowed the complex to continue functioning in 2020 albeit in a limited way.

Table 2. Number of visitors in the SNFCC and average number of visitors per day.

\begin{tabular}{ccc}
\hline Year & The SNFCC's Visitors & $\begin{array}{c}\text { Estimate Average Number of } \\
\text { Visitors Per Day }\end{array}$ \\
\hline $2017^{1}$ & $3,100,000$ & $3,100,000: 365$ days $=8493$ \\
\hline $2018^{2}$ & $5,300,000$ & $5,300,000: 365$ days $=14,521$ \\
\hline $2019^{3}$ & $6,300,000$ & $6,300,000: 365$ days $=17,260$ \\
\hline average $2017-2019$ & $4,900,000$ & 13,425 \\
\hline${ }^{1}$ From June to December 2017; ${ }^{2}$ From January to December $2018[42] ;{ }^{3}$ From January to December 2019.
\end{tabular}

In the period 2017-2019, Christmas marked the peak in the number of guests at the SNFCC. For instance, at Christmas in December 2018, over 700 thousand visitors were recorded; on 30 November 2019, over 40 thousand visitors watched 'the Christmas World' celebration. As many as 34 thousand visitors welcomed 2020. A comparison of the number of residents of the Kallithea district with the number of the SNFCC visitors shows the broad scope of impact of the site, which has become a major recreation venue and an important tourist attraction, known to a broader public rather than just locally. Provided in the SN Park, Cultural Ecosystem Service (CES) benefits (e.g., recreation, physical and 
mental health, aesthetic enjoyment) can be essential for human wellbeing and can foster social cohesion. The growing number of visitors was certainly partially spurred by the strategic approach of the SNFCC administration. They have created a new paradigm of a public space-free and open to everyone, without any kind of barriers.

\section{2. 'Sustainability' of the SNFCC's Program-The Number of Events and Their Role in Popularizing Cultural and Natural Heritage of Greece}

The SNFCC interdisciplinary project plays an important role in popularizing the cultural and natural heritage of Greece. It also offers green education-especially for children and youth [43]. The cultural center was built using funds from the exclusive grant donated by the Stavros Niarchos Foundation. Most of events organized there are free for the public and open to everybody, thanks to an exclusive grant by this foundation. The educational activities and learning opportunities are addressed to people of all ages, especially those who are experiencing financial and social difficulties, thus enabling them to have access to culture-'SNF is dedicated to fostering the vibrancy of civic life, from widely shared access to stellar arts programming, to open dialogue across divides' [44]. Its principle 'focuses on providing cultural stimuli and opportunities for entertainment and learning to people of all ages, while removing economic, social and other barriers to public access to culture' [45].

The goal of the SNFCC program is to deepen the bond between education, society, and creativity. The aim is also to develop a creative society in order to promote the pursuit of a variety of careers in Greece. The courses offered at the center give young and older people an opportunity to access education and learn new competences which are coveted in the job market and useful in daily life. As a result, the center stimulates the engagement of residents in the economy. The SNFCC's educational programs (including art, architecture, nature, and technology workshops) also encourage participants to broaden their range of interests and passions, as well as discover their potential. The program also helps to increase Greece's cultural index-as many as 63\% of inhabitants rank 'low', and only $4 \%$ rank 'high' in terms of cultural participation [18].

In order to discuss the sustainable and flexible approach assumed in the SNFCC program ('sustainable' program), this paper offers a detailed analysis of the number of events organized at the site divided into three major categories: Arts and Culture, Education, and Sport and Wellbeing/Health. The first category is further divided into the following subgroups: music/concerts, cinema, theatre/performances, exhibitions, dance performances and festival/carnival/conference/forum. A variety of courses are offered within each of the subgroups (Table 3).

An integral part of the SNFCC's mission is the promotion of healthy lifestyles. Among the sports facilities, there are: $200 \mathrm{~m}$ of linear running track, $300 \mathrm{~m}$ of elliptical running track and $2 \mathrm{~km}$ of cycle routes (including Evripidou St.). One particularly noteworthy activity is the daily football training sessions organized in the afternoons and in the evenings which-as in the case of other cities-are offered as a measure of preventing criminal activity among the youth. These events are very popular.

The analysis of the events organized at the SNFCC has been carried out based on the programming prepared for every month and published on the center's official website. The set refers to all events in the aggregate (Table 4), taking account of cyclical and periodical activities (e.g., sport activities organized 2-6 times per week, several times a day) andin the case of online activities - those viewed multiple times. The analysis covers the period from 2017 until the end of 2020. Unfortunately, in 2020, the coronavirus pandemic upended the functioning of many cultural facilities and parks [46]. From March to June 2020, many events organized by the SNFCC were cancelled due to the pandemic restrictions (lockdown). Fortunately, the SN Park remained open to the public during 2020 with some limitations. Many events - as is the case with many other cultural facilities-are now being organized via the Internet (data updated as of 31 December 2020). 
Table 3. Selection of courses offered by the SNFCC.

\begin{tabular}{|c|c|c|}
\hline Arts and Culture & Education & Sport and Wellbeing/Health \\
\hline $\begin{array}{l}\text { - } \quad \text { Contemporary art exhibitions; } \\
\text { - } \quad \text { Different genres and styles of music } \\
\text { concerts; } \\
\text { - Theatre performances; } \\
\text { - } \quad \text { Ballet performances; } \\
\text { - Park Your Cinema and Park Your } \\
\text { Cinema Kids; } \\
\text { - Festivals; } \\
\text { - Conferences. }\end{array}$ & $\begin{array}{l}\text { - } \quad \text { Courses for mothers to inspire their kids' reading; } \\
\text { Programs for students of different ages; } \\
\text { - } \quad \text { Literature programs designed for the elderly; } \\
\text { Dialogues-series of lectures which delve into } \\
\text { basic themes of the Foundations: Arts and } \\
\text { Culture, Education, Health and Sports, and } \\
\text { Social Welfare; } \\
\text { - Social Ballroom is a combination of dance } \\
\text { workshops and parties; } \\
\text { - } \quad \text { Art studio; } \\
\text { Meetings for bibliophiles; } \\
\text { Lectures and workshops on botanical and } \\
\text { environmental topics, e.g., tree recognition, } \\
\text { Organic Agriculture and Food Security, } \\
\text { Experiential workshops for the arts and } \\
\text { sustainable development, We make our own } \\
\text { compost-we select the suitable soil for our } \\
\text { plants, Our Land, The Plants that Care for Us: } \\
\text { Spring, A Seed Travels; } \\
\text { Vegetables and Herbs; } \\
\text { Lifelong Learning-courses for elderly; } \\
\text { Cross-cultural Choir; } \\
\text { Panel discussions. }\end{array}$ & $\begin{array}{l}\text { - Gardening courses for the family; } \\
\text { - } \quad \text { Athletic classes and facilities; } \\
\text { - } \quad \text { Daygrounds for children; } \\
\text { - Walk in the Park, Sundays in the } \\
\text { - Park; } \\
\text { - } \quad \text { Team Playing. }\end{array}$ \\
\hline
\end{tabular}

Table 4. Number of all events in the years 2017-2020.

\begin{tabular}{lcccc}
\hline \multicolumn{1}{c}{ Year } & $\mathbf{2 0 1 7}$ & $\mathbf{2 0 1 8}$ & $\mathbf{2 0 1 9}$ & $\mathbf{2 0 2 0}$ \\
\hline Music, concert & 56 & 62 & 68 & 25 \\
\hline Cinema (Park Your Cinema and Park Your Cinema Kids) & 44 & 45 & 24 & 6 \\
\hline Theatre, performance, spectacle & 125 & 217 & 245 & 20 \\
\hline Exhibitions & 7 & 12 & 23 & 13 \\
\hline Dance-performance & 10 & $\mathbf{6}$ & $\mathbf{5}$ & $\mathbf{1 1}$ \\
\hline Festival, carnival, conference, forum & $\mathbf{7 7 4}$ & $\mathbf{1 4 3 1}$ & $\mathbf{9 0 4}$ & $\mathbf{3 1 2 4}$ \\
\hline $\begin{array}{l}\text { Talks/learning, lecture, reading club, reading seminar, } \\
\text { course and workshop, etc. }\end{array}$ & $\mathbf{1 4 5 2}$ & $\mathbf{2 5 4 7}$ & $\mathbf{9 7 8}$ \\
\hline $\begin{array}{l}\text { Sport and wellbeing, walk in the park, virtual tour in the } \\
\text { park, gardening for the family in the Park, etc. }\end{array}$ & $\mathbf{2 4 7 4}$ & $\mathbf{4 3 2 8}$ & $\mathbf{4 4 1 9}$ \\
\hline Total events (with total number of recurring events) & & $\mathbf{1 4 1 5}$ \\
\hline
\end{tabular}

Based on data from 2019, it is estimated that in 2020 there were 336,015 visitors-about 308,360 visitors in the period between January and 13 March 2020 attending the 'live' events and about 27,655 viewers at home via the Internet (Table 5). This figure corresponds to as little as $34.9 \%$ of the total number of visitors, and to $37.8 \%$ as compared to the mean value for the period 2017-2019. The table below (Table 6) contains detailed data on all the events prepared by the SNFCC and released on the Internet (data accessed: 1 January 2021, the updated data are given in brackets). 
Table 5. Number of events and number of participants.

\begin{tabular}{ccccc}
\hline Year & $\mathbf{2 0 1 7}$ & $\mathbf{2 0 1 8}$ & $\mathbf{2 0 1 9}$ & $\mathbf{2 0 2 0}^{\mathbf{1}}$ \\
\hline Number of events & 2474 & 4328 & 4419 & 1415 \\
\hline Number of participants $^{2}$ & 258,973 & 713,667 & 963,000 & $\sim 336,015^{3}$ \\
\hline
\end{tabular}

${ }^{1}$ From January to 13 March 2020 (from 13 March to 21 June the SNFCC was closed), from 22 June to December 2020 the SNFCC functions were mainly online; ${ }^{2}$ Source: https: / /www.snfcc.org/en/news/stavros-niarchosfoundation-cultural-center-three-successful-years-63-million-visitors-2019 (accessed on 2 September 2020); ${ }^{3}$ Estimated data made on the basis of 2019.

Table 6. List of all videos watched on the Internet in 2020.

\begin{tabular}{|c|c|c|}
\hline Event & Number of Films on the Internet & Number of Viewers \\
\hline Music, concerts & 22 films (29 December 2020) & 6109 views \\
\hline Cinema & 0 & 0 \\
\hline Theater and performances & 6 films (4 December 2020) & 1696 views \\
\hline Exhibitions & 0 & 0 \\
\hline Dance & 0 & 0 \\
\hline Festival, carnival, conference & 0 & 0 \\
\hline $\begin{array}{l}\text { Talks/learning, lectures, reading club, } \\
\text { reading, etc. }\end{array}$ & $\begin{array}{c}\text { Reading for kids: } \\
43 \text { films (22 December 2020) } \\
76 \text { films (18 December 2020) } \\
\text { Educational program for kids: } \\
88 \text { films (18 December 2020) }\end{array}$ & $\begin{array}{l}2786 \text { views } \\
2333 \text { views } \\
4621 \text { views }\end{array}$ \\
\hline $\begin{array}{l}\text { Sport and wellbeing, walk in the park, } \\
\text { virtual tour in the park }\end{array}$ & $\begin{array}{c}\text { Tour of the SNFCC: } \\
8 \text { films ( } 5 \text { November } 2020) \\
\text { walk in the Park: } \\
3 \text { films ( } 3 \text { November } 2020) \\
\text { Sport }{ }^{1} \text { : } \\
57 \text { films (9 November } 2020)\end{array}$ & $\begin{array}{l}898 \text { views } \\
550 \text { views } \\
8662 \text { views }^{1}\end{array}$ \\
\hline Total & 303 & 27,655 \\
\hline
\end{tabular}

${ }^{1}$ Detailed information in Table 7.

Table 7. List of sports videos watched on the Internet in 2020.

\begin{tabular}{ccccccc}
\hline Year: 2020 & Yoga & Pilates & Tai Chi & Fit Kids & Exercise and Health & Total \\
\hline Number views & 2270 & 3268 & 991 & 1009 & 1124 & 8662 \\
\hline Number of films & 12 & 15 & 6 & 12 & 12 & 57 \\
\hline
\end{tabular}

Table 7 contains detailed data on sports activities released for the viewers to watch on the Internet (data accessed: 1 January 2021, updated as of 9 November 2020). The most frequently viewed events were sports and concerts.

The survey results can serve as a basis for the following conclusions:

- The proportions of grants donated by the SNF (Figure 12) in the various areas (Art and Culture-30\%, Education-32\% and Health and Social Welfare-the last two areas account for $38 \%$ jointly) are comparable to the proportions between the three categories of events organized by the SNFCC over the years (Figure 15): Art and Culture (from $28.7 \%$ to $36.1 \%$ ), Education (from $21 \%$ to $34.5 \%$ ) and Sport/Wellbeing/Health (between $29.7 \%$ and $42.9 \%$ ). This confirms the consistent policy of the foundation and a conscientious approach to full transparency in financial management [47];

- The obtained data on all events and the proportions between the three distinguished categories (Figures 13 and 16) highlight those which enjoy the most popularity and provide a response to the needs of the community. The particularly high number of sports events (in 2019, they accounted for $70.5 \%$, while in 2020 for $69.1 \%$ of all events) confirms the growing interest in the facility and the increased frequency of visits to the park. Higher demand for educational services confirms the immense contribution by the SNFCC in terms of extending the residents' knowledge and inspiring their 
interests. This applies, for instance, to the assistance targeted at seniors (computer training, activities for persons experiencing problems with memory, etc.). The SNFCC project was designed to achieve a broad, lasting, and positive social impact. Its diverse cultural, educational, and sports programs have particularly focused on the needs of the young and the elderly people as a way of ensuring public welfare $[48,49]$. Such activities are highly relevant because of the effects of the crisis in Greece;

- The creation of the SNFCC with the Park is a factor contributing to the improvement of the quality of residents' life (health and wellbeing); for instance, by offering sports activities, which have a positive effect on physical and mental health, general fitness, mobility, and functionality. The prevalence of sports events in the scheme (Figure 14) shows that many residents have been persuaded to adopt a healthy lifestyle and engage in regular exercise;

- The social and cultural aspects of the sustainable urban improvements are fulfilled during practical functioning of the SNFCC. Its program focusses on providing cultural and ecological stimuli and opportunities for learning to everybody;

- Unfortunately, the COVID-19 pandemic has changed the way in which the citizens use the SNFCC complex. The gradual increase in the number of the events organized by the SNFCC in the period 2017-2019 was unfortunately followed by a drop in 2020-the number of events corresponded to only $37.8 \%$ of the average value for 2017-2019. The lectures organized in 2020 touched upon pertinent topics and aimed at helping the residents whose mental health [50] had deteriorated as a result of the pandemic, i.e., 'Challenges in an ever-changing landscape', 'The limitation of our social life', 'Mentally resistant during quarantine'. Owing to the flexible approach, program modification, and its releases on the Internet, the SNFCC has received subsequent awards in 2020 for its operations.

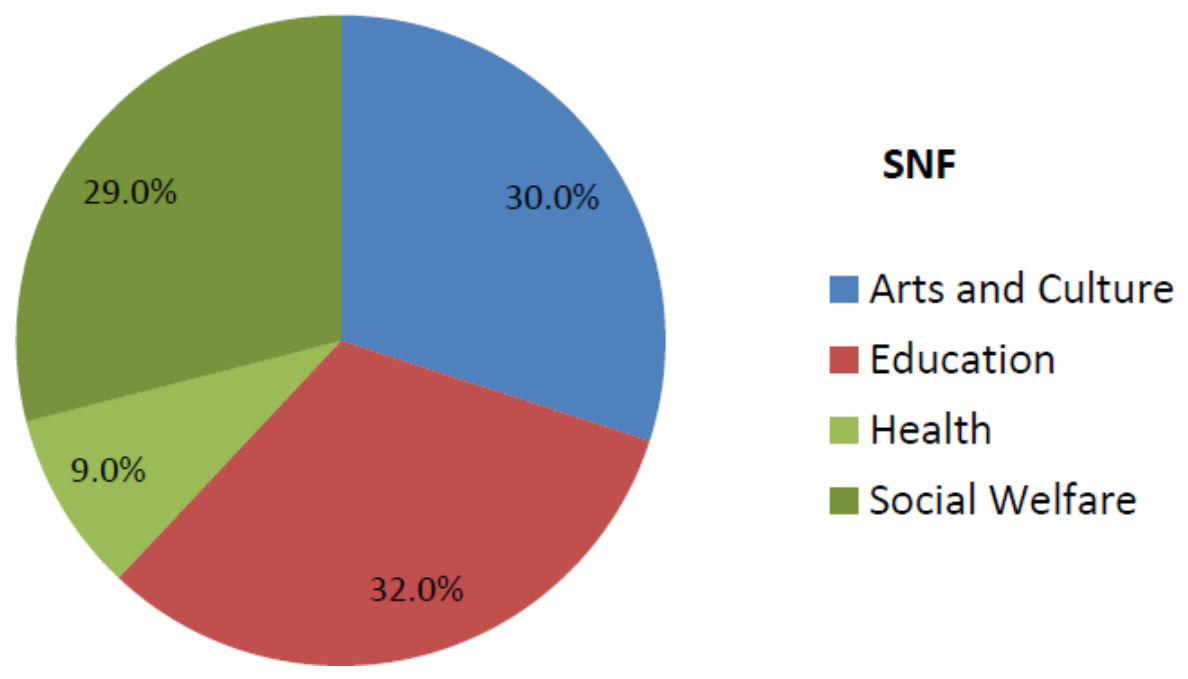

Figure 12. The Stavros Niarchos Foundation's grants in different fields, source: https://www. slideshare.net/Europeana/presentation-it-europeana-cloud-plenary18314 (accessed on 3 April 2014). 

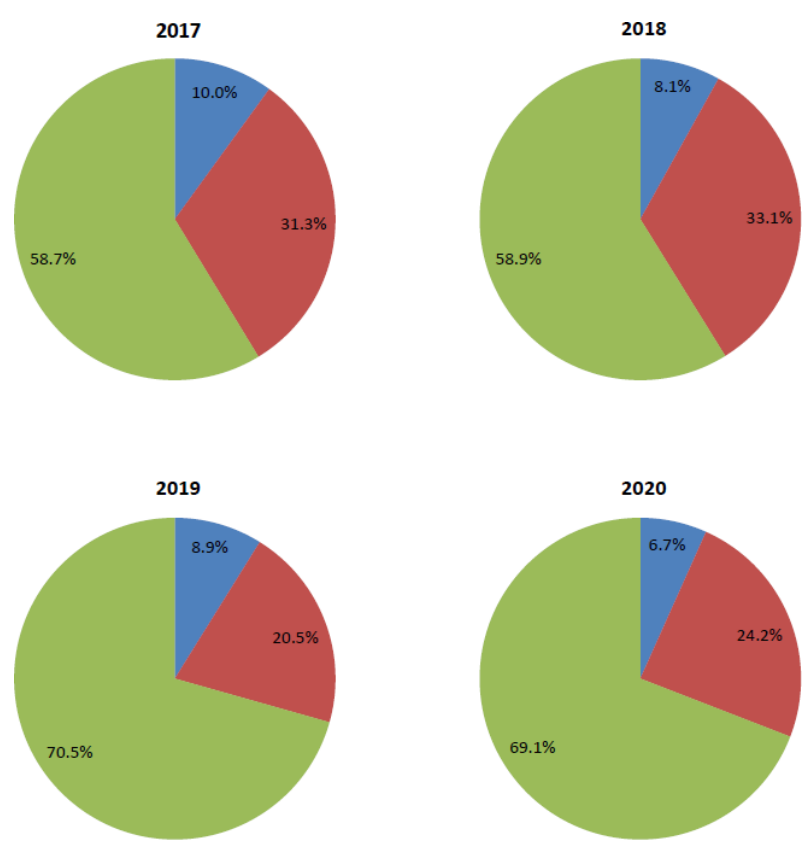

arts and Culture Education $\quad$ - Sport and Wellbeing/Health

Figure 13. All events-the relationship between 3 groups of events: Art and Culture, Education, Sport and Wellbeing/Health.

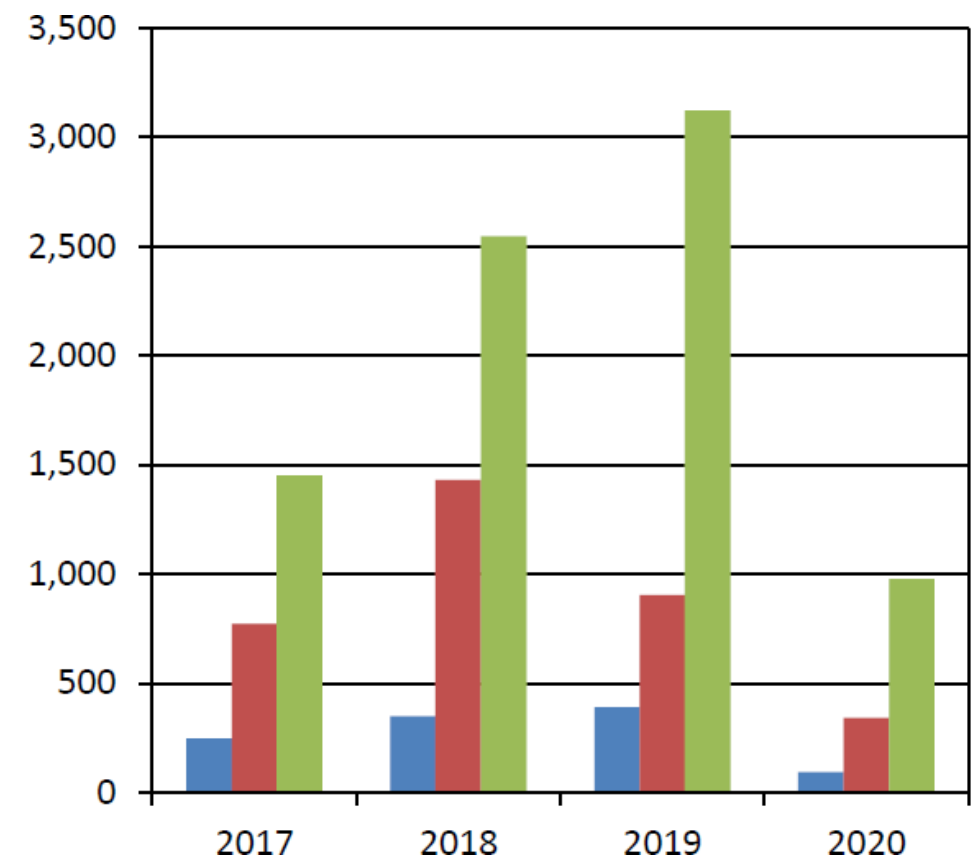

\section{Arts and Culture}

Education

Sport and Wellbeing/Health

Figure 14. Number of 3 groups of all events: Art and Culture, Education, Sport and Wellbeing/Health during 2017-2020. 

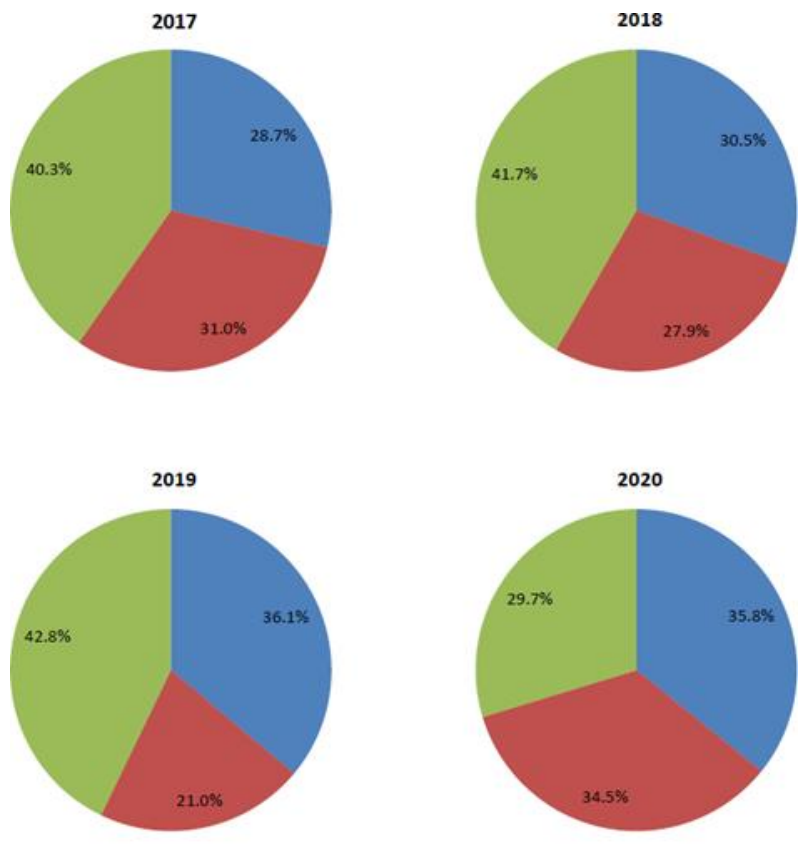

$\|$ Arts and Culture $\quad$ Education $=$ Sport and Wellbeing/Health

Figure 15. Event units-the relationship between 3 groups of events: Art and Culture, Education, Sport and Wellbeing/Health.

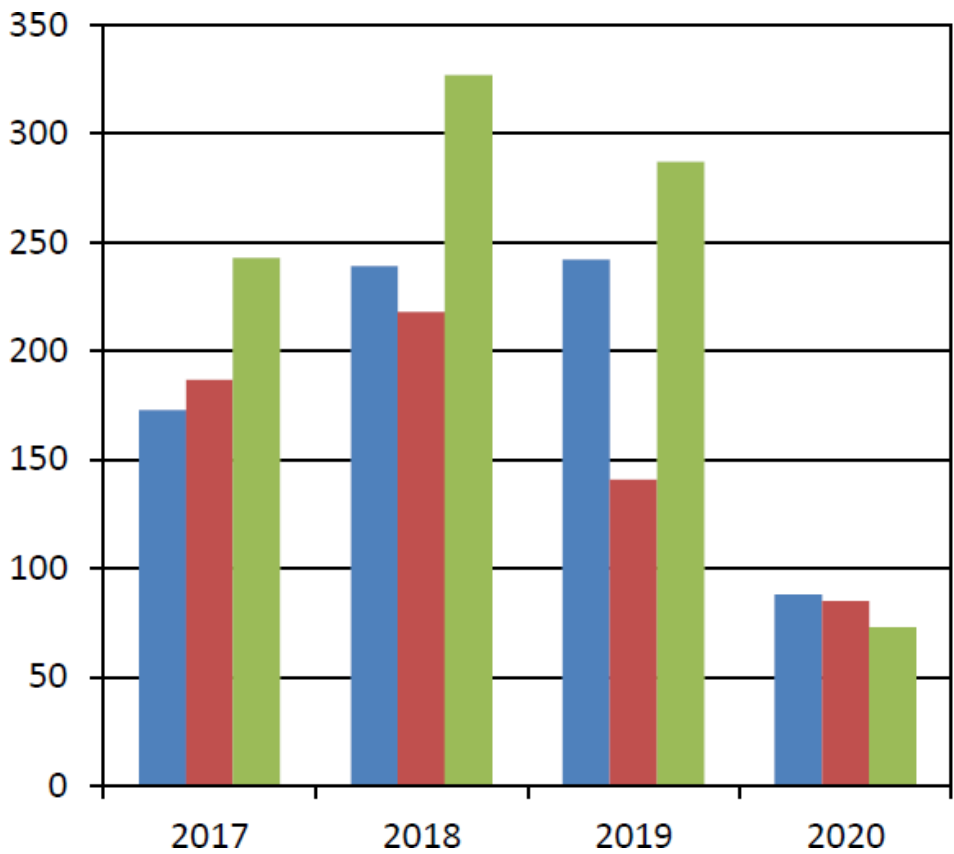

Arts and Culture

Education

Sport and Wellbeing/Health

Figure 16. Number of 3 groups of event units: Art and Culture, Education, Sport and Wellbeing/Health during 2017-2020.

\section{Discussion}

This paper fills a gap in the research on the details of the SNFCC's practical functioning. Its contribution fills some of the gaps in the existing research on the importance of sustainable design from the perspective of practical functioning of sustainable facilities, focusing on the example of the canopy panels as well as the sustainable urban ecology program. The reports on these matters for specific years (except for 2020) are available on the official SNFCC website. However, there are no aggregate studies for the period 
2017-2019 or for 2020. The presentation and comparison of the figures regarding the events organized by the SNFCC illustrates the immense scale of the facility's impact on the visitors. The aim of the study was to show that the creation of the SNFCC with the park areas is a factor contributing to the improvement of the quality of urban space and the quality of life of nearby residents. Program-centered innovation introduced by the SN Park is highly valuable to them. The project contributes to economic and cultural development as well as to the protection and promotion of heritage.

The SNFCC in Athens was chosen as a case study as one of the best examples of a sustainable approach to design and management which enhances Greece's image internationally. The program of the buildings is constantly changing according to users' preferences and requirements, moving them to a new complex era [51-53]. In January 2016, it was expected to be a landmark of inclusion which would enrich the area in terms of Greece's cultural and educational legacy and improve the quality of life for the local community. The results of the study fully confirm the expectations regarding the institution. Before the project was made available for use, the investors assumed that the annual number of SNFCC visitors would reach 700,000 (the Operational Plan). The actual number of visitors and participants of events organized at the site has significantly exceeded these original expectations (average 4,900,000 visitors per year from 2017 to 2019). Undoubtedly, one of the key reasons has been the extensive, continuously updated, and modified cultural-educational-recreational aspects, mostly involving events accessible to the public free of charge. The research substantiates a strong conclusion that the collective benefits from the SNFCC operations are huge and will pay dividends in the future. The extensive, 'sustainable' programming gives participants a chance for development and improves their chances of landing a good job. Importantly, it also provides much needed support during the difficult period of the pandemic. The results of this research confirm the importance of the building and its significant impact range.

Since 2018, the SNFCC has conducted many public surveys among Attica residents and visitors. The purpose has been the periodical evaluation of the SNFCC's public image and the quality of service. In 2019, QED market research in Greece (QED) conducted a survey among 3000 people $-93 \%$ of the residents of Attica were satisfied by the services provided to visitors, and $99 \%$ of them had a positive view of the SNFCC, and as many as $91 \%$ of them considered the SNFCC to be an open and accessible place, which improved the quality of residents' lives and enriched the cultural and natural landscape. The annual survey was carried out through telephone interviews, as well as with visitors to the SNFCC's site. The mentioned survey also indicated that one in two young residents of Attica (over the age of 18) had already visited this place at least once. People selected during research declared that they had visited the SNFCC on average five times [42]. One in two respondents said that they had been there at least once in 2018, while $99 \%$ positively evaluated the venue and its cleaning services [42]. The most frequent visitors were families and people aged between 18 and 44, who were well-educated and predominantly residents of the southern suburbs [47]. The QED survey in 2018 showed that $50 \%$ of the visitors were Athenians (which gives the sum of 2.650 million people among 5.3 million visitors in 2018) [54]. The SNFCC's important aim was fulfilled: creation of a place where the residents of Attica can celebrate important occasions, which can help to build a solid relationship with the local community [55]. The other aim promoting this place as a landmark of contemporary Athens abroad was also fulfilled. According to the survey, tourists in Athens considered the SNFCC a key cultural destination [50]. It became the second most visited place in Greece after the Acropolis [56]. Thanks to collaborations with tourism organization, the numbers of visitors have increased, especially in the summer months. According to the SNFCC's visitor statistics in 2019 (by comparison to 2018), there was a 47\% growth rate in June and $43 \%$ in July. Unfortunately, in the SNFCC's Reports, there is no distinction between the proportion of visitors coming from: Kallithea district, other areas in Athens, elsewhere in Greece, or other countries. According to the survey in 2017, 18,027 children and 22,500 adults participated in the free 'Sports and Wellness' activities organized at the 
SNFCC. In 2017, 6378 adults participated in educational courses on architecture, nature, the arts, and science and technology, including computer courses developing digital skills for users aged over 65 (4060 persons participated in such courses in 2017). The residents of Attica especially benefit from the SNFCC's cultural and educational programs. According to the survey carried out by the SNFCC in $2019,50 \%$ of the residents have already visited this place and over $90 \%$ of Attica residents believe that it improves the quality of life and cultural standards of the city [19]. The research approach adopted for the purposes of this paper differed from the resident survey methodology. The study prepared by the author involved a detailed analysis of the events organized at the SNFCC and the number of visitors. The data on the solar panels' efficiency have been extracted from the reports drafted by the SNFCC. However, the data were presented in a different way (one chart illustrated the figures for the period 2017-2019) compared against the mean temperatures, the daylight hours, and sunshine exposure in Athens.

Certain limitations have hindered the research; for instance, the availability of information and the assumption of a certain degree of generalization of data on the number of the SNFCC visitors and the events organized online. This may have resulted in certain differences in terms of figures collected by the author (Table 5) as compared to the official data (Table 8) from the SNFCC report from the end of 2019. Unfortunately, there is no analogous information about the number of events in 2020.

Table 8. Number of events and activities ${ }^{1}$.

\begin{tabular}{|c|c|c|c|}
\hline Year & 2017 & 2018 & 2019 \\
\hline Number of events and activities & 2942 & 3743 & 3608 \\
\hline
\end{tabular}

The classification of events organized at the SNFCC is not unequivocal. In the classification prepared by the author, conferences, congresses, and festivals were allocated to the Arts and Culture group (rather than to Education), while activities in the garden and the walks were classified to Sport and Wellbeing/Health (rather than as workshops, because they involve physical activity outdoors and 'dynamic' contact with nature). By contrast, 'closed' events organized for schools were not included, because information on such activities is not publicly available. Moreover, there is also no information on the cancellation of planned events publicized in the monthly booklets for the period 2017-2019 (in 2020, during the pandemic, the cancellations were announced); for the purposes of the study, it was assumed that these events did take place. However, this study did not include the guided tours, which are also highly popular: more than 1800 free guided tours were organized in Greek and in English (mainly dedicated to foreign tourists) in 2017. Additionally, one source could not be found online: the Booklet from January 2017-the lack of the data for one month constitutes $2.8 \%$ of the total amount of 36 months which were analyzed. Insofar as the number of SNFCC visitors was concerned, the publicly available data may be generalized-the visitors do not necessarily engage in the events organized at the site and cannot be included for the purpose of the analysis.

Regarding the remaining limitations, one should mention:

- The lack of updated data on the population of the Kallithea district in 2020 - the data from 10 years ago are still being used (from the last the population census from 16 March 2011);

- No detailed information on the efficiency of the panels from October 2019 to December 2020 or on the number of persons visiting the site in 2020 could be obtained from the SNFCC;

- The limited availability of information in the English language.

The role of a contemporary urban park has undergone a major transformation. Intended to serve as a refuge from city noise in the past, urban parks are now being designed to ensure the fullest possible integration with the city, and aspire to engage the residents 
by providing them with cultural and recreational benefits [ 57,58$]$. This role is particularly pertinent given the diminishing urban green areas and the difficult epidemiological situation. The authors have already conducted research focused on the problem of deficits of green areas in cities. The publications have touched upon the search for the new forms and technologies applied in urban gardens occupying a limited space, including green walls and roofs $[59,60]$. The innovative parks integrate the urban tissue, improve its quality, and contribute to the revival of the adjacent areas. Often - as in the case of the SNFCC - they comprehensively combine a variety of auxiliary functions in their vast programming offers. The introduction of such an innovative cultural-educational program at the SNFCC has significantly changed our perception of an urban park. It has drawn our attention to the social issues and the necessity to ensure good living conditions to the residents of the local community. The SNF grants and public funding have been allocated to meet the needs of regular people (including those facing exclusion as a result of their lower social status or country of origin) and are not used to generate profits for private institutions and investors.

The COVID-19 pandemic has already changed the perspective and the way in which we use our public spaces and parks. In central and eastern Europe, the number of visitors is declining. The visitor volume decreased to as little as $40-50 \%$ of the $2018-2019$ numbers [46]. The number of persons visiting the SNFCC in 2020 (including the 'virtual' visits) corresponded to ca. $52 \%$ as compared to the mean numbers of 2017-2019. The findings of this study pave the way for further investigations. The problem of sustainable development [61] and the adjustment of programming by cultural institutions and parks to the dynamic situation is important, and thus further research is planned in this area. The SNFCC and the other buildings of major cultural institutions with the LEED Platinum have radically changed our perception of the public space and the park, e.g., Vestas Technology and Development Center in Århus, Denmark; Museum of Water and Life in Hemet, USA; Park Ventures in Bangkok, Thailand. Those projects help cities to improve their international competitiveness and attract foreign visitors [58].

\section{Conclusions}

The research results justify the following conclusions:

- $\quad$ The SNFCC interdisciplinary project plays an important role in popularizing the cultural and natural heritage of Greece;

- The fact that the SNFCC project has met high ecological standards makes it an endeavor of European relevance. It is one of the leading examples of environmental sustainability across three levels: design and construction, operation, footprint in the local ecosystem and social welfare ('sustainable' program). The best practices in terms of environmental standards implemented at the SNFCC guarantee the sustainability of its operations. The ecological aspects of sustainability performed in the SNFCC contribute to stability of the climate in the neighborhood, improvement in the quality of air, and the renewal of biodiversity. Tangible benefits on the local ecosystem are already apparent in the Park. The Kallithea district has become a more inclusive, safe, and sustainable settlement for inhabitants;

- The sustainable project of the SNFCC, which fulfils the urban ecology criteria, has been very well received by the visitors-citizens and tourists alike. The sustainability of this complex extends beyond the structure of the buildings and the SN Park. The SNFCC's practical functioning thanks to the 'sustainable programme' contributes to other benefits such as the health and wellbeing of residents, quality and accessibility of education, and reduction in inequalities [56]. It offers green and cultural education to all visitors, especially children and youth;

- The development of high-quality buildings and the SN Park is a factor contributing to the improvement of the quality of urban space and the quality of residents' lives. It also contributes to the increased value of the neighboring areas in the Kallithea district and influences a property boom [53]. The sports activities organized at the 
site contribute to the improvement of public health and help to promote a healthy lifestyle;

- The SN Park continued to operate during the pandemic in 2020, which was a crucial element for citizens during this difficult time;

- The SN Park is an approach to create a deep link between nature and society according to urban political ecology. In this social and ecological process, local plants became a second nature based on Greek landscapes;

- Introduced Ecosystem Services in the SNFCC project moderate natural phenomena (flood control, water purification, and climate regulation);

- Provided in the SN Park are Cultural Ecosystem Services benefits (e.g., recreation, physical and mental health, aesthetic enjoyment), which may contribute to fostering social cohesion. They can be essential for human wellbeing and can contribute to a sense of place (topos). In the SN Park, there are a few urban spaces indicated on the map (Figure 4) which play an important role for the local community.

Funding: This research received no external funding.

Institutional Review Board Statement: Not applicable.

Informed Consent Statement: Not applicable.

Data Availability Statement: Data are available in publicly accessible repositories of the SNFCC. They are all shown in the 'References' section.

Acknowledgments: The author would like to thank the anonymous reviewers for their thorough work with the manuscript and for providing constructive and insightful comments on this paper.

Conflicts of Interest: The author declares no conflict of interest.

\section{References}

1. Ruble, B.A. The Challenges of the 21st Century City. Urban Sustainability Laboratory. Wilson Center. Available online: www.wilsoncenter.org/publication/the-challenges-the-21st-century-city (accessed on 6 December 2012).

2. Papageorgiou, M.; Gemenetzi, G. Setting the grounds for the Green Infrastructure in the metropolitan areas of Athens and Thessaloniki: The role of green space. Eur. J. Environ. Sci. 2018, 8, 82-92. Available online: https://www.researchgate. net/publication/325897837_Setting_the_grounds_for_the_Green_Infrastructure_in_the_metropolitan_areas_of_Athens_and_ Thessaloniki_the_role_of_green_space (accessed on 12 October 2020). [CrossRef]

3. Cranz, G.; Boland, M. Defining the Sustainable Park: A Fifth Model for Urban Parks. Landsc. J. 2004, 23, 102-120. Available online: https://www.researchgate.net/publication/250231365_Defining_the_Sustainable_Park_A_Fifth_Model_for_Urban_ Parks (accessed on 12 October 2020). [CrossRef]

4. Nielsen, A.B.; van den Bosch, M.; Maruthaveeran, S.; van den Bosch, C.K. Species richness in urban parks and its drivers: A review of empirical evidence. Urban Ecosyst. 2013, 17, 305-327. Available online: https://www.researchgate.net/publication/25 7671090_Species_richness_in_urban_parks_and_its_drivers_A_review_of_empirical_evidence (accessed on 12 September 2020). [CrossRef]

5. Benedict, M.A.; McMahon, E.T. Green Infrastructure: Smart Conservation for 21st Century. Renew. Resour. J. 2002, 20, 12-17. Available online: https:/ / www.merseyforest.org.uk/files/documents/1365/2002+Green+Infrastructure+Smart+Conservation+ for+the+21st+Century.pdf (accessed on 12 September 2020).

6. Smets, J.; De Blust, G.; Verheyden, W.; Wanner, S.; Van Acker, M.; Turkelboom, F. Starting a Participative Approach to Develop Local Green Infrastructure: From Boundary Concept to Collective Action. Sustainability 2020, 12, 10107. Available online: https:/ / www.mdpi.com/2071-1050/12/23/10107 (accessed on 12 September 2020).

7. Drapella-Hermansdorfer, A. Współczesny Park Miejski w Europie. Available online: https://docplayer.pl/3164332-Wspolczesnypark-miejski-w-europie.html (accessed on 12 October 2020).

8. Wolski, P. Współczesny park miejski w Europie. In Wizja Rozwoju Wojewódzkiego Parku Kultury i Wypoczynku im. Gen. Jerzego Ziętka. Materiaty Konferencyjne; Urząd Marszałkowski Województwa Śląskiego: Katowice, Poland, 2006; pp. 1-9. Available online: https://slaskie.pl/images/wpkiw / pw_wpme.pdf (accessed on 12 October 2020).

9. Zachariasz, A. Współczesne kierunki i tendencje w projektowaniu parków publicznych. Nauka Przyr. Technol. 2009, 3, 1-10.

10. Zachariasz, A. Zieleń jako Wspótczesny Czynnik Miastotwórczy ze Szczególnym Uwzzględnieniem Roli Parków Publicznych; Wydawnictwo Politechniki Krakowskiej: Kraków, Poland, 2006. Available online: https://www.researchgate.net/publication/332080375 Zielen_jako_wspolczesny_czynnik_miastotworczy_ze_szczegolnym_uwzglednieniem_roli_parkow_publicznych (accessed on 2 September 2020). 
11. Zachariasz, A. A Park in a Small Town. On the Value of Place and Maintenance of Tradition. In 7ULAR: Middle-Sized Cities of Tomorrow; Juzwa, N., Sulimowska-Ociepka, A., Eds.; Wydawnictwo Politechniki Śląskiej: Gliwice, Poland, 2013; pp. $209-215$. Available online: https://www.researchgate.net/publication/343006692_A_PARK_IN_A_SMALL_TOWN_ON_THE_VALUE_ OF_PLACE_AND_MAINTENANCE_OF_TRADITION (accessed on 21 September 2020).

12. Makowska, B. Ogrody przy muzeach w Paryżu/The gardens near museums in Paris. Czas. Tech. 2010, 5- $A, 179-188$.

13. Makowska, B. Parki rzeźb w Norwegii/The Sculpture Parks in Norway. Czas. Tech. 2012, 2-A, 203-208. Available online: https:/ / repozytorium.biblos.pk.edu.pl/redo/resources/31199/file/suwFiles/MakowskaB_ParkiRzezb.pdf (accessed on 2 September 2020).

14. Schneider-Skalska, G. Witruwiusz-prekursor projektowania zrównoważonego. Czas. Tech. 2009, 1-A, 127-131. Available online: https: / / repozytorium.biblos.pk.edu.pl/redo/resources/33761/file/suwFiles/SchneiderSkalskaG_WitruwiuszPrekursor. pdf (accessed on 2 September 2020).

15. Newhouse, V. Chaos and Culture: Renzo Piano Building Workshop and the Stavros Niarchos Foundation Cultural Center in Athens; Monacelli Press: New York, NY, USA, 2017.

16. Awards. Available online: https://www.snfcc.org/en/awards (accessed on 12 September 2020).

17. Stavros Niarchos Foundation Cultural Center 2017 Report. Available online: https://www.snfcc.org/sites/default/files/sitefiles_ 2019-07/apologismos_eng_1.7.19.pdf (accessed on 12 September 2020).

18. SNFCC Impact Study Report for SNF Board of Directors. Available online: https://www.snf.org/media/4960627/SNFCCImpact-Study-Detailed-Report-EN.pdf (accessed on 29 January 2020).

19. Stavros Niarchos Foudation Cultural Center. Available online: https://www.snfcc.org (accessed on 12 September 2020).

20. Pafi, M.; Siragusa, A.; Ferri, S.; Halkia, M. Measuring the Accessibility of Urban Green Areas: A Comparison of the Green ESM with Other Datasets in Four European Cities; JRC Technical Reports; Publications Office of the European Union: Luxembourg, 2016. Available online: https://publications.jrc.ec.europa.eu/repository/bitstream/JRC102525/190916_siragusa_\%20jrc_techrep_ accessibility_online.pdf (accessed on 12 September 2020).

21. Kalfa, F.; Kalogirou, N. Quality through Sustainable Practices during the Design and Construction Phase-The case of the SNFCC. Procedia Environ. Sci. 2017, 38, 781-788. [CrossRef]

22. Asprogerakas, E. Strategic Planning and Urban Development in Athens. The Current attempt for Reformation and future challenges. In Proceedings of the Sustainable Urban Planning and Design Symposium, Nicosia, Cyprus, 13 May 2016. Available online: https://www.researchgate.net/publication/320695579_Strategic_Planning_and_Urban_Development_in_Athens_The_ Current_attempt_for_Reformation_and_future_challenges (accessed on 8 October 2020).

23. Sardianou, E.; Leonti, A. Applying the Contingent Valuation Method in Assessing Urban Parks: The Case of Niarchos in Greece. IOP Conf. Ser. Earth. Environ. Sci. 2019, 362, 1-6. Available online: https://www.researchgate.net/publication/337289250_ Applying_The_Contingent_Valuation_Method_in_Assessing_Urban_Parks_the_Case_of_Niarchos_in_Greece (accessed on 12 October 2020). [CrossRef]

24. Bakogiannis, E.; Kyriakidis, C.; Siti, M.; Floropoulou, E. Reconsidering Sustainable Mobility Patterns in Cultural Route Planning: Andreas Syngrou Avenue, Greece. Heritage 2019, 2, 104. [CrossRef]

25. Deborah Nevins \& Associates. Available online: https://www.dnalandscape.com/athens.html (accessed on 24 August 2020).

26. Clark, D. Green Space per Inhabitant in the City of Athens in Greece in 2018. Statista. Available online: https:/ /www.statista. com/statistics / 860773/green-areas-per-inhabitant-in-athens-in-greece (accessed on 4 September 2020).

27. Feltynowski, M.; Kronenberg, J.; Bergier, T.; Kabisch, N.; Łaszkiewicz, E.; Strohbach, M.W. Challenges of urban green space management in the face of using inadequate data. Urban For. Urban Green. 2018, 31, 56-66. Available online: https://www. sciencedirect.com/science/article/abs/pii/S1618866717304569 (accessed on 12 October 2020). [CrossRef]

28. Forde, T. Satellite Images Ranks Europe's Greenest (and Not so Green) Cities. Available online: https://www.archdaily.com/88 3707 / satellite-images-ranks-europes-greenest-and-not-so-green-cities (accessed on 20 September 2020).

29. London 'Greenest City' in Europe. Available online: https://www.edie.net/news/6/London--greenest-city--in-Europe-/ (accessed on 20 September 2020).

30. Prajsner, A. Które z Naszych Miast jest Najbardziej “Zielone”? Available online: https: / / forsal.pl/artykuly /1027174,ktore-znaszych-miast-jest-najbardziej-zielone.html (accessed on 20 September 2020).

31. Dímos Kallithéas. Municipality in Attica. Available online: https://citypopulation.de/en/greece/attiki/4801_d\%C3\%ADmos_ kallith\%C3\%A9as / (accessed on 12 September 2020).

32. Kallithea. Euromed. Available online: http:/ /www.reseau-euromed.org/en/ville-membre/kallithea-2/ (accessed on 12 September 2020).

33. Wikipedia. Population Density in Athens. Available online: https://en.wikipedia.org/wiki/File:Population_Density_in_Athens. PNG (accessed on 12 September 2020).

34. Daniels, E. The Area I Live in: Kallithea. Available online: https://slideplayer.com/slide/13793946/ (accessed on 8 October 2020).

35. Wikipedia. 1896 Summer Olympics. Available online: https://en.wikipedia.org/wiki/1896_Summer_Olympics (accessed on 12 September 2020).

36. Europa dla Obywateli. Available online: https://europadlaobywateli.pl/partnerzy/municipality-of-kallithea// (accessed on 12 September 2020). 
37. Ateny Klimat (Grecja). Available online: https://pl.climate-data.org/europa/grecja/ateny/ateny-7/ (accessed on 12 September 2020).

38. Weather Atlas. Monthly Weather Forecast and Climate Athens, Greece. Available online: https://www.weather-atlas.com/en/ greece/athens-climate\#daylight_sunshine (accessed on 12 September 2020).

39. Surface Air Temperature for December 2019, Implemented by ECMWF, Copernicus 2019. Available online: https://climate. copernicus.eu/surface-air-temperature-december-2019 (accessed on 12 September 2020).

40. SNFCC. Energy. Available online: https://www.snfcc.org/en/energy (accessed on 8 September 2020).

41. SNFCC. Impact Study Report for SNF Board of Directors. Available online: https://www.snf.org/media/4963854/SNFCCImpact-Study-Report-FINAL-EN.pdf (accessed on 8 September 2020).

42. Stavros Niarchos Foundation Cultural Center SNFCC. Three Successful Years-6.3 Million Visitors in 2019. Available online: https: / / www.snfcc.org/en/news/stavros-niarchos-foundation-cultural-center-three-successful-years-63-million-visitors-2019 (accessed on 12 September 2020).

43. SNFCC. Monthly Booklets. Available online: https://www.snfcc.org/en/monthlyevents (accessed on 8 September 2020).

44. An Innovative Collaboration Reimagines and Reactivates Public Space for a New Era, from New York to Athens. Available online: https: / /www.snf.org/en/newsroom/news/2020/12/an-innovative-collaboration-reimagines-and-reactivates-publicspace-for-a-new-era (accessed on 3 December 2020).

45. SNFCC. Culture. Available online: https://www.snfcc.org/en/snfcc/our-work/culture (accessed on 8 September 2020).

46. Hodor, K.; Przybylak, Ł.; Kuśmierski, J.; Wilkosz-Mamcarczyk, M. Identification and Analysis of Problems in Selected European Historic Gardens during the COVID-19 Pandemic. Sustainability 2021, 13, 1332. Available online: https://www.mdpi.com/2071 -1050/13/3/1332 (accessed on 1 March 2021). [CrossRef]

47. SNFCC. Close Collaboration between the SNFCC and the Stavros Niarchos Foundation. Available online: https://www.snfcc. org/en/news/close-collaboration-between-snfcc-and-stavros-niarchos-foundation/1240 (accessed on 8 September 2020).

48. Visitors to SNFCC Reach 5.3 Million in 2018. Available online: https://www.ekathimerini.com/238024/article/ekathimerini/ life/visitors-to-snfcc-reach-53-million-in-2018 (accessed on 8 September 2020).

49. The Stavros Niarchos Foundation. Available online: https:/ /www.efc.be/member-post/stavros-niarchos-foundation-2/ (accessed on 8 September 2020).

50. SNFCC. Pandemic: Challenges in an Ever-Changing Landscape. Available online: https://www.snfcc.org/en/PandemicLectures (accessed on 12 September 2020).

51. Oberfrancová, L.; Legény, J.; Špaček, R. Critical Thinking in Teaching Sustainable Architecture. World Trans. Eng. Technol. Educ. 2019, 17, 127-133. Available online: http://www.wiete.com.au/journals/WTE\&TE/Pages/Vol.17,\%20No.2\%20(2019)/01 -Spacek-R.pdf (accessed on 18 January 2021).

52. Stavros Niarchos Foundation Cultural Center. Presentation it European Cloud Plenary 18 March 2014. Available online: https:/ / www.slideshare.net/Europeana/presentation-it-europeana-cloud-plenary18314 (accessed on 8 September 2020).

53. Gkinni, Z.; Tsaroucha, C.; Sarris, N. The National Library of Greece: Moving into a new era. In Proceedings of the World Library and Information Congress, 83rd IFLA General Conference and Assembly, Wrocław, Poland, 19-25 August 2017. Available online: https:/ / www.researchgate.net/publication/340447525_The_National_Library_of_Greece_moving_into_a_new_era (accessed on 8 September 2020).

54. Kampouris, N. Over Five Million Visit Athens' Stavros Niarchos Cultural Center in 2018. Available online: https://greekreporter. com/2019/02/25/over-five-million-visit-athens-stavros-niarchos-cultural-center-in-2018/ (accessed on 18 January 2021).

55. Greek City Time. Over 6.3 Million People Visit Stavros Niarchos Foundation Cultural Centre in 2019. Available online: https:/ / greekcitytimes.com/2020/01/30/over-6-3-million-people-visit-stavros-niarchos-foundation-cultural-centre-in-2019/ (accessed on 18 January 2021).

56. Andriopoulou, E. The Stavros Niarchos Foundation Cultural Center: A Case Study of a Public-Private Partnership for the Benefit of Society. Available online: https:/ / www.wtflucerne.org/snfcc-as-ppp-success-story (accessed on 18 January 2021).

57. Markou, M. Renovation Projects at Faliro Bay. Available online: https://www.athenssocialatlas.gr/en/article/faliro-bay/ (accessed on 12 October 2020).

58. Fotiadi, I. The SNFCC in Athens Local Improvement Rekindles a District. Goethe Institut. Available online: https://www.goethe. $\mathrm{de} / \mathrm{en} / \mathrm{kul} / \mathrm{ges} / \mathrm{eu} 2 / \mathrm{rhr} / 21017619 . \mathrm{html}$ (accessed on 8 September 2020).

59. Makowska, B. Green elevations and roofs of the buildings (the 5th elevation) in 21st century cities. In Future of the Cities-Cities of the Future; Gyurkovich, J., Wójcik, A., Eds.; Wydawnictwo Politechniki Krakowskiej: Kraków, Poland, 2014; pp. 29-50.

60. Makowska, B. Ogrody i Parki w Miastach Hiszpanii/Gardens and Parks in Spain Cities. Czas. Tech. 2012, 6, 235-243. Available online: https:/ / repozytorium.biblos.pk.edu.pl/redo/resources/30944/file/suwFiles/CzasopismoTechniczne_z.19.Architektura_ z.6-A.pdf (accessed on 2 September 2020).

61. How Many Buildings in the World are LEED Platinum Certified? Design Ideas for the Built World. Available online: https:/ / caddetailsblog.com/post/how-many-buildings-in-the-world-have-become-leeds-platinum-certified (accessed on 12 October 2020). 